\title{
'Five' as a typological number in the medieval Arabic grammatical tradition
}

\author{
BeAta ShEYhatovitch (Tel Aviv University)
}

\begin{abstract}
In the Arabic grammatical tradition several categories comprising exactly five members can be found, e.g., the types of "meaningful things", of definite nouns, of tanwīn, of definite article, of tawābic etc. Given the importance of the number 'five' in Islam, it is natural to ask whether these categorizations are affected by the symbolical meaning of that number. This article examines some of these categorizations in order to check the extent to which they are linguistically or theoretically justified, and whether they use 'five' as a typological number. In order to answer these questions, the fivefold divisions are tested for consistency and the surrounding discourse is investigated.

Key words: Medieval Arabic grammatical tradition, typological numbers, definiteness, bayān, tanwīn, tawābic, 'atf al-bayān
\end{abstract}

\section{Introduction}

Organizing material into short lists may be a powerful mnemonic and pedagogical tool, but in light of the frequent use of the specific number 'five' in Arabic grammatical literature, we ask whether this particular number has a special meaning and what that meaning can be.

Various cultures ascribe symbolic and even magical significance to numbers. Numerical symbolism in monotheistic religions is probably related to the Pythagorean tradition, which holds that the cosmic order can be expressed by numbers. This tradition views odd numbers in general as auspicious (and even numbers as boding ill). In cultures influenced by this tradition, ritual acts and prayers are repeated an odd number of times. ${ }^{1}$ Among various meaningful numbers, the number five is related to the pentagonal symmetry, to the five senses, etc. (although, unlike three and seven, five is not considered mysterious). ${ }^{2}$

1 See SCHIMMEL 1993: 12-14.

2 LAROCHE 1995: 571. 


\section{Beata Sheyhatovitch}

In Islamic tradition (influenced by Greek ideas), the number 'five' seems to have a special significance - particularly well-known are the five pillars of Islam and the five daily prayers. In Islamic jurisprudence there are al-'ahkām al-hamsa 'the five qualifications', namely, al-wājib 'obligatory', al-mustahibb 'recommended', al-mubāh 'indifferent', almakrūh 'reprehensible', and al-harām 'forbidden'. ${ }^{3}$ In Islamic theology there are almugayyabāt al-hams 'the five mysteries', a technical term denoting the five things known only to God. They are the hour of the Last Judgment; when rain will be sent down; what is in the womb (namely, the sex and number of children); the livelihood one will obtain on the morrow; and when one will die. ${ }^{4}$

'Ihwān al-Șafă' "The Brethren of Purity" (the authors of the encyclopedic Rasä'il 'Ihwān al-Safa $\vec{a}^{3}$; were active in Bașra in the $10^{\text {th }}$ century ${ }^{5}$ ) used numerical symbolism extensively, and seem to have given a special role to the number 'five': in their view, it signifies $t a b \bar{l}^{c} a$ 'Nature' (that can be divided into celestial nature and the four elemental natures) ${ }^{6}$ the five senses correspond to the five types of Nature, ${ }^{7}$ and also to the five moving planets. ${ }^{8}$ In addiPage| 82 tion, 'Ihwān al-Ṣafā' distinguish "five interior faculties". ${ }^{9}$ Interestingly, Ibn Sīnā speaks of "five interior senses", in addition to the five "exterior senses". 10

Given the above-mentioned evidence for the importance of the number 'five' in Islam, to which we add that in the Arabic grammatical tradition several categories comprising exactly five members can be found, it may be assumed that, at least in some cases, grammarians made efforts to organize the linguistic data into fivefold categories, the number 'five' being considered an auspicious number. In this article I will examine several such categorizations (the categorizations of "meaningful things", definite nouns, tanwins, definite articles and $t a w \bar{a} b i$ ), and discuss the question of the extent to which the divisions into five types are linguistically or theoretically justified in these cases, or whether the number 'five' is used typologically. ${ }^{11}$

3 SCHACHT 1960: 257. See LARCHER 1992: 363-365 for a pragmatic- and logic-oriented discussion of al'ahkām al-ḩamsa.

4 The editors of $E I^{2}$ 1993: 346-347.

5 See MARQuet 1971 for a discussion on Rasä'il 'Ihwān al-Safâ'.

6 See NASR 1993: 51-52, 60-61 for a discussion.

7 Ibid.: 96.

8 Ibid.: 101.

9 See ibid.: 102 for a discussion.

10 See ibid.: 250 for a discussion.

11 The notion of typological numbers is widely used in Bible research-see, e.g., STONE 2011: $69 \mathrm{ff}$ CONRAD 1988 applies this notion to Islamic historiographical literature, claiming that some numbers are used there not in their literal sense, but "to express a general idea of magnitude, proliferation, or great extension" (ibid.: 45).

jais 19 (2019): 81-111 


\section{Five types of meaningful things}

Al-Jāhiz (d. 868/869) presents in his Kitāb al-Bayān wa-l-Tabyīn "the five modalities of clarity" ('adawāt al-bayān al-hams). Bayān (translated by Montgomery as "clarity""12) is a complex term, whose meaning varies from one source to another. ${ }^{13}$ Al-Jāhiz defines it as follows:

Clarity is a noun which comprises everything which removes for you the headscarf [enveloping] the concept and tears down the veil [covering] the inmost mind, so that the auditor may attain its true reality and seize upon its product whatever that clarity actually is and no matter what type of sign is used ${ }^{14}$ (wa-l-bayānu smun jāmi ${ }^{c} u n$ likulli šay’in kašafa laka qinā'a l-ma'nā wa-hataka l-hijāba dūna l-ḍamīri hattā yufḍ̄a

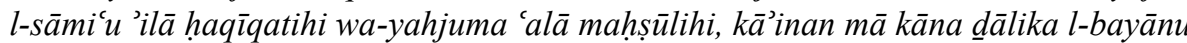
wa-min 'ayyi jinsin kāna l-dalīlu). ${ }^{15}$

From his study of Kitāb al-Bayān, Montgomery concludes that "for Jāhiz, bayān is a twoway process in which both locutor and auditor participate, and to which they both contribute. [...] His notion of bayān is not narrowly aesthetic, but is rather the heaven-sent gift of communication". ${ }^{16}$ Indeed, "the five modalities of clarity" cover all imaginable types of communication:

All varieties of signs, verbal and non-verbal, for concepts [amount to] five things, no less, no more: the first is the oral expression, then gesture, then counting, then writing, then the condition which is called location (nișba). 'Location' is the signifying condition, which can take the place of those [other four] varieties and which is no less efficacious than those [other four] $\operatorname{signs}^{17}$ (wa-jamī ${ }^{c} u$ 'așnāfi l-dalālāti 'alā $l$ -

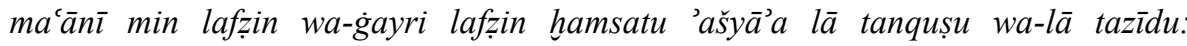

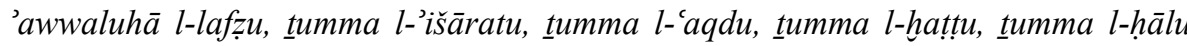
llatī tusammā niṣbatan. wa-l-niṣbatu hiya l-ḥālu l-dāllatu, llatī taqūmu maqāma tilka l-'așnāfi wa-lā taqṣuru 'an tilka l-dalālāti). ${ }^{18}$

These modalities, save for the last one, are clear enough. ${ }^{19}$ As for niṣba, it is one of the Arabic translations suggested for the Greek to keisthai (the other options were wad ${ }^{c}$ and mawd $(\bar{u})$, one of the ten Aristotelian categories, that can be translated into English as "be-

12 MONTGOMERY 2006: $103 \mathrm{ff}$.

13 See BERNAND 1995 for a discussion on the term bayān in 'ușūl al-fiqh; MONTGOMERY (2006: 122-133) explores the concept of bayān in the Qư'ān and in al-Jāhiz's view.

14 This translation is taken from MONTGOMERY 2006: 127-128.

15 Al-Jāḥiz, Bayān I: 76

16 MONTGOMERY 2006: 133.

17 This translation is taken from ibid.: 128 , with some slight changes.

18 Al-Jāḥiz, Bayān I: 76. See RoN-GILBOA (2017: 147-156), who, based on this fragment from Kitāb alBayān and discussions from Kitāb al-Hayawān, concludes that al-Jāhiz views the entire universe as a "semiotic system", in which each phenomenon is a sign that can be deciphered by a careful observer.

19 See MONTGOMERY 2006: 129-131 for a discussion. 


\section{Beata Sheyhatovitch}

ing-in-a-position". ${ }^{20}$ According to al-Jāhiz, this modality of clarity refers to phenomena of the natural world that can be interpreted, for instance, as signs of God's presence. ${ }^{21}$ Montgomery claims that there was "an intellectual and polemical connection between the legal-

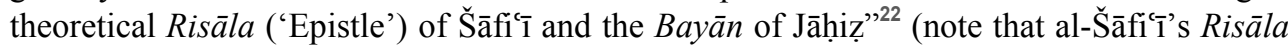
also presents five wujūh 'modalities' of bayān, ${ }^{23}$ and so does al-Jașșāṣ' Fuṣū ${ }^{24}$ ).

In the grammatical literature, traces of these ideas can be found in discussions of the definition of 'word' by Ibn Ya'īš (d. 1245) and al-'Astarābādīi (d. circa 1289).

At the beginning of his al-Mufașşal, al-Zamahšarī (d. 1144) defines kalima 'word' as al-lafżatu l-dāllatu 'alà ma'nan mufradin bi-l-waḍ' $i$ 'an expression unit that signifies by its coinage ${ }^{25}$ a simple meaning,. ${ }^{26}$ While explaining components of this definition, Ibn Yac $1 \bar{s}$ notes that there are five types of "meaningful things" (al-'ašya $\bar{a}^{\prime}$ al-dālla): al-hatt, al-'aqd, al-'išăra, al-niṣba, al-lafz ${ }^{27}$ (the same categories mentioned by al-Jāhiz).

Ibn al-Hājib (d. 1249) defines 'word' as lafž wuḍi'a li-ma'nan mufradin 'an expression that was coined for a simple meaning ${ }^{28}$ (a definition that is very close to al-Zamahšarī’s, which is to be expected, given the proven affinity between the latter's al-Mufașsal and Ibn al-Hājib's al-Muqaddima al-Kāfiya ${ }^{29}$ ). Al-'Astarābādī explains this definition, and says that mentioning lafz is necessary because it excludes from the definition al-hatt, al-'aqd, alniṣba and al-išăra, which may signify a simple meaning by their coinage, but cannot be considered words. ${ }^{30}$

20 MONTGOMERY 2006: 128-129.

21 See ibid: : 129-130 and RON-GILBOA 2017: 154-156 for a discussion.

22 MONTGOMERY 2006: 102.

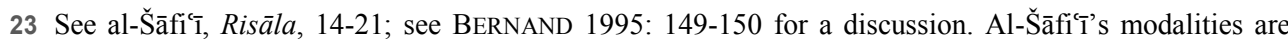
completely different from the categories mentioned by al-Jāhiz; however, MONTGOMERY (2006: 131) links between al-Šâfi' ‘’’s notion of ijtihād and al-Jāḥiz's notion of niṣba (the fifth modalities of clarity in their respective systems).

24 Al-Jașșāṣ (Fușūl II: 14-19) discusses al-Šāfiç̄’s classification of bayān types. He also mentions (ibid: 31) a classification similar to al-Jāḥiẓ’s, attributing it to “one ancient scholar”. See BERNAND 1995: 152 for a discussion.

25 Coinage $\left(w a d^{\prime}\right)$ is an important term in Muslim philosophy, theology and jurisprudence. In the gram-

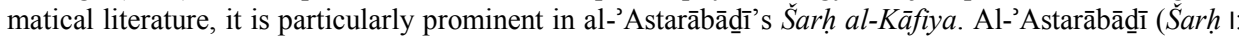
21) explains the phrase "the coinage of a linguistic expression" (waḍ" al-lafz) as "the first assignment of [a linguistic expression] to a meaning, with an intention that it will become conventional between people." An element's coinage determines its form, meaning, categorical identity, syntactic functions, etc. (although in actual use there can be certain deviations from those primary properties of the element). Al'Astarābād̄î's theory of coinage is discussed in SHEYHATOVITCH 2018: 84-127.

26 Ibn Ya‘̄̌š, Šarh I: 18. See GuILlaume 2011: 51-53 for a discussion of al-Zamahšarī’s definition (with a stress on its Aristotelian origin).

27 Ibn Ya'̄̄̌s, Šarḥ I: 19.

28 Al-'Astarābādīi, Šarḥ I: 19.

29 See Sheyhatovitch 2018: 1 for a survey of some opinions on this issue. Guillaume (2011: 56) views this definition as Ibn al-Hājib's version of "the standard definition".

30 Al-'Astarābād̄ī, Šarh ı: 22-23. See SHEYhATOVITCH 2018: 84-87 for an additional discussion of al'Astarābādī’’s definition of 'word'. See also GUILLAUME 2011 and LARCHER 2011. 
Both Ibn Ya'īš and al-'Astarābād̄i state that the function of the word lafz 'a [linguistic] expression' in the definition of 'word' is to exclude from it four other types of "meaningful things", including hatt. The distinction between lafz and hatt, or, in other words, between spoken and written language, is natural in a book of rhetoric and literary criticism such as al-Jāhiz's (because rhetorical and stylistic devices used in oral speech may be different from those used in writing), but seems artificial in the context of a definition of 'word'. A word is a word no matter whether it is written or spoken, and any book of grammar is abundant with examples of written words that are referred to as words. Ibn Ya $\mathrm{Y}-\check{\mathrm{is}}$ and al'Astarābādīi's attempts to exclude writing from the definition of kalima are therefore very surprising. These attempts may be explained by the influence of al-Jāhiz and/or by the importance of the number 'five'.

\section{Five types of definite nouns}

Starting with Sībawayhi (d. 796), most Arabic grammarians speak of five categories of definite nouns; however, some of them have difficulty with fitting the relative pronouns into this model.

Sībawayhi's categorization is as follows:

Definite nouns are five things: nouns that are proper nouns; nouns that are annexed to definite nouns, if you do not have in mind the idea of tanwin, (i.e., if the annexation is real); [nouns prefixed by] the definite article; vague nouns; personal pronouns

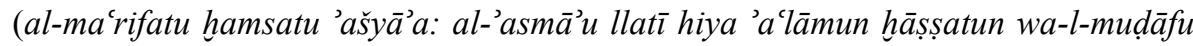
'ilā l-ma'rifati 'id̄ā lam turid ma'nā l-tanwīni, wa-l-'alifu wa-l-lāmu wa-l-'asmā'u lmubhamatu wa-l-'iḍmāru). ${ }^{32}$

Sībawayhi explains that 'vague nouns' are demonstrative pronouns ('asmä' al-'išāra), that are definite because they are used to point at a thing to the exclusion of the rest of its kind. ${ }^{33}$ Al-Mubarrad (d. 899/900), Ibn al-Sarrāj (d. 929), ${ }^{34}$ al-Zajjājī (d. 948/949/950), Ibn Jinnī (d. 1002), and Ibn al-'Anbārī (d. 1119) mention the same five categories ${ }^{35}$ (although Ibn Jinnī

31 Interestingly, a similar fivefold division of meaningful things appears in al-Suhaylī's Natä’ij al-fikr fì l-naḥw in a discussion of 'an al-mufassira. Al-Suhaylī refers to them as kalām al-nafs 'the speaking of the self'. See SADAN (forthcoming), Section 3.3 for a discussion of the refevant excerpt.

32 Sībawayhi, Kitāb I: 187. See MAROGY 2010: 99-149 for a pragmatics-oriented discussion on the notion of definiteness in Sībawayhi's Kitāb.

33 Sībawayhi, Kitāb ı: 187-188. SAKAEDANI (2019: 236-237) notes that Sībawayhi does not mention relative pronouns in this list, but does include them with demonstratives in the category of al-'asmä' almubhama (which she translates as "ambiguous nouns") in Bāb tahqīr al-'asmä' al-mubhama 'The chapter on the diminutive forms of the vague nouns' (Sībawayhi, Kitāb II: 141-142). She concludes that he found similarities between demonstratives and relatives, although he did not express them clearly.

34 See SAKAEDANi 2019: 237-240 for a discussion on al-Mubarrad and Ibn al-Sarrāj's categorizations.

35 Al-Mubarrad, Muqtaḍab IV: 276; Ibn al-Sarrāj, 'Ușūl ı: 143; Ibn Jinn̄̄, Lumac, 159-167; al-Zajjājīi, Jumal, 27, 192; Ibn al-'Anbārī, 'Asrār, 341-342. 
in Kitāb al-Luma' uses the term 'asmä' al-'išāra instead of mubhamāt ${ }^{36}$ ). The order of categories (and, correspondingly, the hierarchy of definite nouns) varies from one author to another. $^{37}$

Al-Zamahšarī seems to be the first grammarian who explicitly included the relative pronouns in the category of mubhamāt, together with demonstratives, in the context of discussing definite nouns. His list of categories is: "proper nouns" (al-'alam al-hāssṣ), "personal pronouns" (al-mudmar), "vague nouns, that include two things: demonstrative pronouns and relative pronouns" (al-mubham wa-huwa šay'āni 'asmä'u l-'išārati wa-l-mawșūlātu), "[nouns] prefixed by the definite article" (al-dāhil 'alayhi harfu l-ta'rīfi), "nouns annexed in

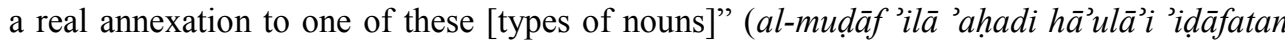
haqĩqiyyatan). ${ }^{38} \mathrm{Ibn} \mathrm{Ya}^{\mathrm{c}} \overline{\mathrm{is}} \mathrm{s}$ explains that the principal difference between mubham and mudmar, vague and pronominalized constituents, is that a vague constituent is elucidated by a constituent that follows it, whereas a $3^{\text {rd }}$ person pronoun is elucidated by a constituent that precedes it, i.e., by its antecedent. ${ }^{39}$

Ibn 'Ușfūr (d. 1271) presents the following five categories of definite nouns: personal pronouns, demonstrative pronouns, proper nouns, nouns prefixed by the definite article, nouns annexed to definite nouns in a real annexation. He includes relative pronouns in the category of nouns preceded by the definite article, stating: fa-'ammā l-mawșūlātu fa-min qabìli mā 'urrifa bi-l-'alifi wa-l-lämi, but mentions a controversy related to the question of whether they are made definite by an overt article or an intended one. ${ }^{40}$

Ibn 'Ușfūr presents two different opinions: according to 'Abū 'Alī l-Fārisī (d. 987), relative pronouns "are definite by the previous knowledge (i.e., by virtue of information that is known equally to the speaker and the addressee), represented by the relative clause" (ta'arrafat bi-l-'ahdi llaḍi fi li l-ṣilati). According to 'Abū 1-Hasan al-'Ahfaš (d. 825-835), relative pronouns are definite due to the definite article. The former opinion is supported by the fact that some relative pronouns come without the definite article (for instance, $m \bar{a}$ and $m a n$ ). The latter is supported by the claim that definiteness can exist only with the definite article or annexation, while the case of $m \bar{a}$ and man is explained by analogy to sahar 'this dawn': if the latter refers to the dawn of the day on which the utterance is produced, it is considered as definite (and thus is diptote), but comes without the definite article, due to 'adl 'anomaly'. ${ }^{41}$ The view that alla $\underline{d} \bar{\imath}$ etc. are definite due to the definite article may be challenged by the claim that some relative pronouns can create annexation structures, but the answer would be that when functioning as an annexed

36 Ibn Jinn̄̄, Luma', 159.

37 See GÄTJE 1970, GABUČAN 1972: 40-41, and MAROGY 2010: 117-123 for a discussion of some of such categorizations.

38 Ibn Yacī̌š, Šarh V: 85.

39 Ibid.: 86. This excerpt is discussed in GÄTJE 1970: 234-235 (GÄTJE translates mubham as "unbegrenzt"). See also SAKAEDANI 2019: 240-242.

40 Ibn 'Uṣ̂ūr, Šarḥ I: 148.

41 Ibn 'Ușfūr, Šarh II: 237; see SHEYHATOVITCH 2016: 316 for an analysis of al-'Astarābād̄ī's discussion on sahar. See CARTER 1981: 76, 79 for a discussion of 'anomaly' as a factor "preventing full declinability" (as formulated in CARTER 1981: 74). 
element, the relative pronoun is definite due to the annexation, and its original definiteness is ignored. ${ }^{42}$

Al-’Astarābād̄ī, similarly to Ibn Ya ${ }^{\text {č }} \overline{\mathrm{s}}$, regards relative pronouns, together with demonstrative pronouns, as mubhamāt, ${ }^{43}$ but explains the reason for their definiteness differently: he does not consider them as definite due to the definite article (he says that their definiteness resembles that of nouns preceded by al- ${ }^{44}$ implying that it is not the same). Also, he does not accept the view that the relative pronoun is definite due to the relative clause: he argues that if the relative clause could render other constituents definite, it should also have rendered definite the noun rajul in the sentence jă $\overline{a n}^{\prime} \mathbf{r}$ rajulun darabtuhu "A man whom I hit came to me". ${ }^{45}$ So what is al-'Astarābādī̄'s explanation for the relative pronoun's definiteness?

The definiteness of the relative pronoun is due to its coinage as a definite noun that is used to refer to a thing known to the speaker and the addressee, [whereas the common knowledge regarding that thing is] the content of the relative clause [that follows that pronoun] (ta'rīfu l-mawșūli bi-waḍihi ma'rifatan mušāran bihi 'ilā $l$ ma'hūdi bayna l-mutakallimi wa-l-muhātabi bi-maḍūni șilatihi). ${ }^{46}$

In other words, the definiteness of allad $\bar{\imath}$ should be explained by the hypothetical coiner's intention rather than by a formal factor.

To sum up, the above-mentioned grammarians accept the fivefold division of definite nouns, although some of them obviously struggle to find a right place for relative pronouns within their categories. Hence it is not surprising that some grammarians challenged the accepted categorization and treated relative pronouns as a separate category.

Ibn Mālik (d. 1274) presents the definite nouns as follows:

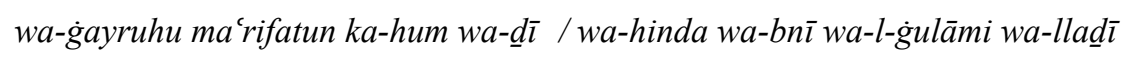

And the other nouns (i.e., that differ from indefinite nouns mentioned beforehand) are definite, like hum 'they', $\underline{d} \bar{\imath}$ 'this (fem.)', / Hind, $i b n \bar{\imath}$ 'my son', al-gilàm 'the servant', and alla $\underline{\imath}^{-47}$

Ibn 'Aqīl (d. 1367) in his commentary of this verse explicitly speaks of six types of definite nouns: al-muḍar 'personal pronouns', ism al-'išâra 'demonstrative pronouns', 'alam 'proper nouns', al-muhallāt bi-l-'alif wa-l-lām '[nouns] provided with a definite article', almawșūl 'relative pronouns', mā 'udīfa 'ilā wāhidin minhā '[nouns] that are annexed to one of [these types of definite nouns]'. ${ }^{48}$

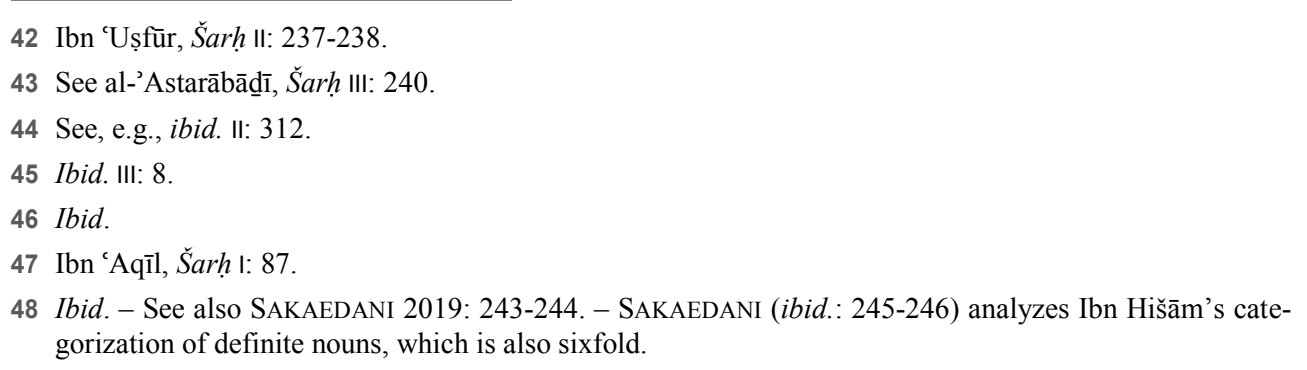




\section{Beata Sheyhatovitch}

\section{Five types of tanwīn}

Some grammarians distinguished between five types of tanwin, perhaps in order to match the five categories of definite nouns. ${ }^{49}$ Sïbawayhi, al-Mubarrad and Ibn al-Sarrāj do not treat various functions of tanwin systematically (though they occasionally mention them in

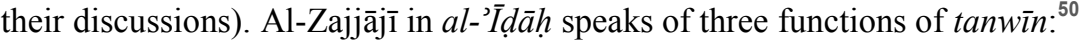

(1) It may mark the distinction between mutamakkin (lit. 'powerful; established', fully declinable $)^{51}$ and light constituents, on the one hand, and heavy constituents that are not fully declinable, on the other hand; ${ }^{52}$

(2) It may serve as compensation ('iwad) for an omitted part of the word-for example, the form jawārin 'female slaves' is derived from a supposed original form *jawāriyu in raf or *jawāriyi in jarr; the sequences -iyu and -iyi are considered "heavy", and therefore $y \vec{a}$ ' becomes quiescent; then the pattern of the word becomes deficient, and the word is joined by a compensating tanwīn, becoming *jawāriyn, and then the $y \bar{a}^{3}$ is omitted, because it is a quiescent letter followed by a vowelless $n \bar{u} n$. This is the process by which the form jawārin is obtained. ${ }^{53}$ Al-Zajjājī uses this as a central example in his discussion on "a compensating tanwin", as its tanwīn is clearly unrelated to tamakkun because the word is diptote by its pattern.

(3) It may make it possible to distinguish between definite and indefinite states in proper nouns and interjections whose ending is usually left unchanged. For instance, the proper noun 'Amrawayhi retains its ending as long as it is used as semantically definite, but once it becomes semantically indefinite (namely, when it is used to signify a class of objects ${ }^{54}$ ), the proper noun takes a tanwin to signify that it is used as an indefinite noun. For instance, hā $\underline{d} \bar{a}$ 'amrawayhi wa-marartu bi-'amrawayhin 'āhara 'This is 'Amrawayhi and I passed by another [man named] 'Amrawayhi'. ${ }^{55}$

49 See GABUČAN 1972: 55-56 for a discussion of al-'Ušmūn̄̄s (d. 1464) view of tanwīn as an indefinite article, and of modern linguists who adopted this view. AYOUB (1991: 169 ff.) examines this view, and concludes that it is insufficient as an explanation of all appearances of tanwin, given that proper nouns such as Zayd take tanwin despite their semantic definiteness. She offers a more complicated explanation for the tanwin function: it is related to the nominality of the noun in different modules (the module of logical form, the module of cases and the syntactic module). See ibid.: 207-209 for a discussion.

50 The following excerpt is translated and discussed also in VERSTEEGH 1995: 168-176.

51 Mutamakkin is an active participle derived from the term tamakkun, which, in DANECKI's (2009: 431) words, "is used for a general grammatical and semantic category indicating the ability of words to be inflected and perform various grammatical functions". See AYOUB 2018: 33, fn. 44 for a survey of various translations offered by modern scholars for this term. AYOUB (2009: 443), AYOUB (2018: 37), and DANECKI (2009: 431) relate the notion of tamakkun in Sībawayhi's Kitāb to the notions of heaviness/lightness. In AYOUB's (2018: 38) words, "the notion of tamakkun refers to mobility in syntactic position, semantic mobility, morphological flexibility, and wide referential capability".

52 Al-Zajjājīi 'Ị̇āh 97.

53 Ibid.: 97-98.

54 See MAROGY 2009: $115 \mathrm{ff}$. for a discussion of cases when proper nouns "lose their specific character and become applicable to each member of a whole class so named".

55 Al-Zajjājī' 'Ị 'ibrāhīmin in marartu bi-'ibrāhìma wa-'ibrāhīmin 'āhara as tanwīn al-tamakkun (and points out that

\footnotetext{
jis 19 (2019): 81-111
} 
Al-Zamahšarī is probably the first grammarian to speak of five types of tanwin. They are the following:

(1) Al-dāll 'alā l-makāna 'signifying the status'. According to Ibn Ya'ǐš, this type of tanwin signifies that the noun retains its nominal status, becoming neither like a particle (which would render the noun mabnī) nor like a verb (which would render the noun diptote). ${ }^{56}$ This type of tanwin parallels the first type mentioned by al-Zajjājī.

(2) Al-fäșil bayna l-ma'rifa wa-l-nakira 'distinguishing between the definite and indefinite [noun]'. ${ }^{57}$ This parallels the third type mentioned by al-Zajjājī.

(3) Al-'iwad min al-mudâf 'ilayhi 'compensation for an [omitted] governed element'. Unlike al-Zajjājī, who concentrates on the morphophonological aspects of the phenomenon and speaks of "compensating tanwin" in relation to words whose third root consonant is $w \bar{a} w$ or $y \bar{a}$, al-Zamahšarī and Ibn $\mathrm{Ya}^{c} \overline{1} \mathrm{~s}$ speak here about forms such as yawma'idin 'that day', where, according to Ibn Ya'ǐš, the tanwin compensates for an omitted clause (or clauses). For instance, Q 99:1-4: 'id̄ā zulzilat-i l-'arḍu zilzālahā wa-'ahrajat-i l-'arḍu 'ațqālahā wa-qāla l-'insānu mā lahā yawma'ididin tuhaddițu 'ahbārahā 'When earth is shaken with a mighty shaking and earth brings forth her burdens, and Man says, "What ails her?", upon that day she shall tell her tidings'. The reconstructed original structure is: ...yawma'idin tuzalzalu l-'ardu zilzālahā watuhriju l-'arḍu 'atqqālahā wa-yaqūlu l-'insānu mā lahā... 'Upon the day when earth is shaken with a mighty shaking and brings forth her burdens, and Man says, "What ails her?", [she shall tell her tidings]'.

The three clauses that should have functioned as a governed element of the first word were omitted, and the tanwin took their place. The form should have been *yawma'idn, and a kasra was added after the $\underline{d} \bar{a} l$ to prevent a sequence of two vowelless consonants. ${ }^{58}$

(4) Al-nā'ib manāb harf al-'itlāq "[tanwīn] that takes the place of the long vowel of a loose rhyme". ${ }^{59}$ Traditional Arabic poetic theory recognizes two types of rhyme (qäfiya), muqayyada 'fettered' and mutlaqa 'loose'. In the former, the rhyme consonant is not followed by a letter of prolongation. In the latter, a letter of prolongation is attached. Various types of rhyme where the rhyme consonant is followed by a short vowel and a vowelled or quiescent $h \bar{a}^{\text {’ }}$ are also called 'loose rhyme'. ${ }^{60}$ So al-

classifying the tanwins of 'amrawayhin and of 'ibrähimin as belonging to two different categories is somewhat problematic - see ibid.: 445). It can be concluded that tanwin as a marker of indefinite nouns (widely known as tanwin al-tankīr) is irrelevant for originally diptote proper nouns that receive tanwin due to their semantic indefiniteness. That is because once 'ibrähìm ceases to be semantically definite, it ceases to behave as a diptote proper noun, behaving instead as a regular triptote noun. Consequently, it is appropriate for it to take tanwin al-tamakkun.

56 Ibn Ya īšs, Šarh IX: 29. See AyOUB 2009: 443 for a discussion of this excerpt.

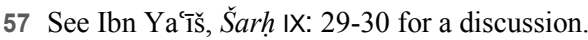

58 Ibid.: 30. See ibid.: 31-33 for additional examples.

59 Ibid.: 29

60 See BONEBAKKER 1978: 412. 


\section{Beata Sheyhatovitch}

Zamahšarī speaks here of a tanwīn used instead of a vowel prolongation at the end of poetry verses, a practice characteristic of Banū Tamīm's recitation.

(5) Al-tanwīn al-g்ăli 'extravagant $\operatorname{tanw}_{\bar{l} n}{ }^{61}$, that joins only a 'fettered' rhyme. ${ }^{62}$

Interestingly, al-Zamahšarī presents tanwīn as one of the "exclusive attributes" (hașā̉iṣ) of a noun ${ }^{63}$ (which does not prevent him from distinguishing five types of tanwin, including those peculiar to poetry, that can also join verbs). Ibn Ya ${ }^{c} 1 \check{s}$ notices this theoretical difficulty, and resolves it by explaining that when speaking of a tanwin as an exclusive attribute of a noun, al-Zamahšarī has in mind tanwīn al-tamkīn only (called al-dāll 'alā l-makāna by alZamahšarī), which indeed is attached only to nouns, in order to distinguish between those that are fully declinable and those that are not. Ibn Ya $\mathrm{a}^{\mathrm{i}} \mathrm{s}$ says that al-Zamahšarī could not have meant "an absolute tanwīn" (muțlaq al-tanwinn, i.e., tanwin in general), as this category includes also tanwin al-tarannum that can also join verbs. ${ }^{64}$

After explaining the first three types of tanwīn mentioned by al-Zamahšarī, Ibn Ya ī̌s states that the fourth type is tanwin al-tarannum, which appears only in poetry and is related to rhyme ${ }^{65}$ (in Ayoub's words, it is used "so as to produce a musical effect" ${ }^{\text {"66 }}$ ). Nün can replace letters of prolongation, which it resembles, being a nasal consonant. Tanwin altarannum can, in turn, be divided into two types: a tanwin that makes the verse's structure and pattern complete, and a tanwin that is added after all parts of the verse are present. The former is added in a loose rhyme, the latter in a fettered rhyme. The two types of tanwin altarannum correspond to al-Zamahšarī's fourth and fifth types. Ibn Ya c $^{\text {ĭš }}$ criticizes alZamahšarī for classifying those as two separate types of tanwīn, and also for omitting another type-tanwīn al-muqābala 'tanwīn of comparison'. This tanwīn is added to proper nouns that have the form of the sound feminine plural. For instance, Muslimāt, when functioning as a feminine proper noun, is expected to be diptote (like any feminine proper noun); however, it takes a tanwin, to match the nün of the ending of sound masculine plural forms, such as muslimūna. ${ }^{67}$

To sum up, Ibn Ya $\mathrm{a}^{\mathrm{i}} \mathrm{i} \mathrm{S}$ recognizes the following five types of tanwīn: li-l-farq bayna mā yanșarifu wa-mā là yanșarifu, al-dāll 'alā l-nakira, tanwīn al-'iwaḍ, tanwīn al-tarannum, tanwīn al-muqābala. ${ }^{68}$ It seems that he chose to join the two types of rhyme-related tanwīns under the title tanwin al-tarannum in order to maintain the fivefold categorization.

Ibn 'Ușfūr presents the same five types: tanwīn li-l-tamakkun, tanwīn al-tankīr, tanwīn al-muqābala, tanwīn al- 'iwad (unlike al-Zamahšarī and Ibn Ya ${ }^{c} \overline{1} \check{\mathrm{s}}$, he mentions in this context both cases like yawma ididin and cases like jawārin), tanwīn al-tarannum (he mentions

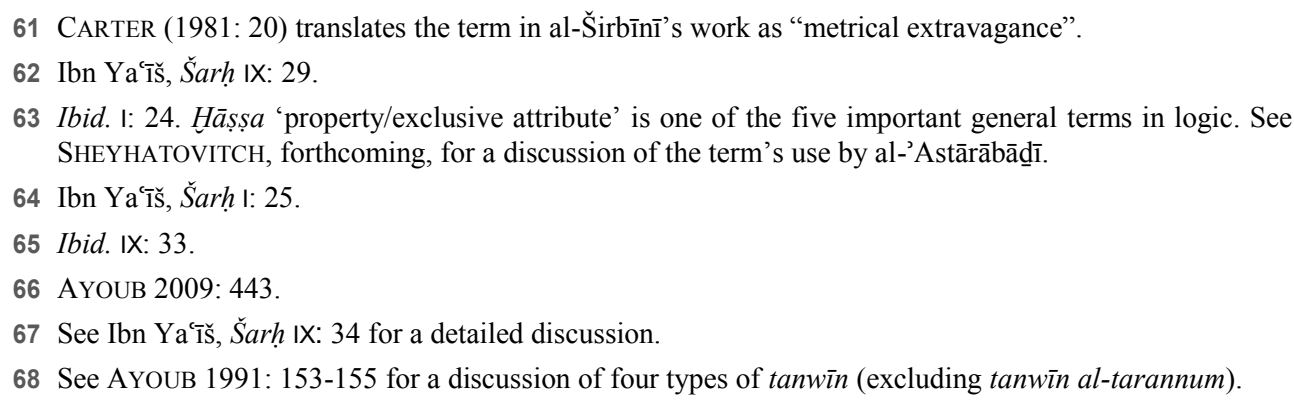

jais • 19 (2019): 81-111 
only the case of loose rhymes, i.e., the first of the two cases mentioned by Ibn Ya $\left.{ }^{c} 1 \check{s}\right)$; he stresses that all types except for the last-mentioned one join only nouns. ${ }^{69}$

Al-'Astarābād̄i deals with tanwīn in a chapter dedicated to "the exclusive attributes of a noun" (hawāṣ al-ism). ${ }^{70}$ He mentions the same five types of tanwīn, distinguishing from the outset between tanwin al-tarannum, that can join various constituents, and the other four types, that are added to nouns only. ${ }^{71}$ Unlike the grammarians we mentioned before, who limit tanwīn al-tankīr to certain proper nouns and interjections, al-'Astarābādī says that the ending of the proper nouns in rubba 'aḥmadin wa-'ibrāhīmin 'many men named 'Ahmad and 'Ibrāhīm' is not only the marker of indefiniteness, but also a marker of establishment ${ }^{72}$ which is the case also with the ending of rajulun 'a man', since there are particles/morphemes (harf) that perform two functions simultaneously. If rajulun functions as a proper noun, its tanwin should be construed as a marker of establishment only. ${ }^{73}$

Al-'Astarābādī's discussion of tanwīn al-muqäbala is relatively detailed and complicated. He does not limit this type of tanwin to proper nouns, but notes that the fact that it is retained in proper nouns, e.g., in Q 2:198 min 'arafātin 'from 'Arafāt', proves that it is not a marker of establishment (since proper nouns that are feminine by form or meaning should be diptote) nor of indefiniteness (because proper nouns are definite) ${ }^{74}$ However, his final conclusion is that it is "[a marker] of full declension and establishment" (li-l-sarf ${ }^{75}$ wa- $l$ tamakkun). At this point he needs to explain why this tanwīn is not omitted in min 'arafätin. His explanation is as follows:

If [the tanwin] was omitted, it would have been followed by the kasra in the omission, and the nașb would have followed [the omitted kasra]. That would have differed from the usual state of affairs in the sound plural, where the kasra is followed by others, instead of following others (li-'annahu law saqața la-tabi'ahu l-kasru fi lsuqūti, wa-tabica l-naṣbu, wa-huwa hilāfu mā 'alayhi l-jam'u l-sālimu 'id-i-i l-kasru fîhi matbū'un lā tābi un $)^{76}$

In other words, if 'arafät had been a diptote noun, it would not have taken kasra, as a consequence of its not receiving a tanwinn. ${ }^{77}$ Thus, its ending in jarr would have become identical to its ending in naṣb, which should not happen in the sound plural, in which

69 Ibn 'Ușfūr, ک̌arḥ I: 36-40.

70 See al-'Astarābād̄ī, Šarh I: 43-50

71 Ibid: : 45-49.

72 Ibid.: 45. In such cases, the Arab grammarians usually view the tanwin as a marker of establishmentsee fn. 55 above.

73 Al-'Astarābād̄ī, Šarh I: 45.

74 Ibid.: 46.

75 See ÅKESSON 2009 for a discussion of the term șarf; see AYOUB 2018: 34 ff. for a comparison between the terms related to tamakkun and șarf.

76 Al-'Astarābād̄ī, Šarh ı: 47.

77 Al-'Astarābā the omission of the tanwin. See ibid: : 102-103 for a discussion. 


\section{Beata Sheyhatovitch}

naṣb generally behaves analogously to jarr, but not vice versa. ${ }^{78}$ According to al'Astarābād̄ī, the tanwīn in min 'arafātin resembles a tanwīn in a diptote noun that received it "due to poetic license" (li-l-darüra), as there was something that prevented the tanwīn's omission. ${ }^{79}$

It should be mentioned that al-'Astarābād̄i considers tanwīn, regardless of its specific function, a marker of a word's end and an indicator that the word is not an annexed element (dāllan 'alà tamāmi l-kalimati wa-'annahā gayru mud̄äfatin). This trait is common to the tanwin and the nün of the suffix of the dual and sound masculine plural, but the above-mentioned five functions pertain to tanwin only. ${ }^{80}$

Despite the problematic status of tanwin al-tarannum (which can join nouns and verbs, and thus seems to contradict the claim that tanwin is an exclusive attribute of a noun), and despite blurring the difference between tanwīn al-muqäbala and tanwīn altamakkun, al-'Astarābād̄ī keeps speaking of five types of tanwīn.

Al-Širbīn̄i (d. 1570) views tanwīn as one of the identifying features of a noun. He focuses on the four types of tanwin that are added only to nouns: tanwin al-tamakkun (he mentions that it is called also tanwīn al-'amkaniyya and tanwīn al-șarf ${ }^{81}$ ), tanwīn altankīr (which, like most grammarians, he limits to ba'd al-'asmä' al-mabniyyāt 'certain invariable nouns'), ${ }^{82}$ tanwīn al-muqābala (which he does not limit to proper nouns), tanwīn al-iwad. As for the latter type, al-Širbīnī says that it joins nouns such as $\dot{g} a w \bar{a} s ̌ i n$ 'covers' and jawārin "in compensation for the arbitrarily omitted yā" ('iwadan min-a l-

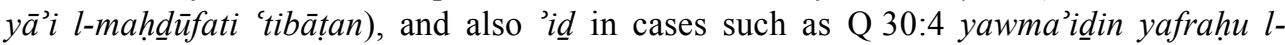
mu'minūna 'on that day the believers shall rejoice, where the tanwin compensates for the omitted governed element (which should be a clause). Al-Širbīnī cites Ibn Hišām (d. 1360), who argues that the tanwīn in kullun 'all' and ba'dun 'some' is also tanwin al'iwad that compensates for an omitted governed element. Al-Širbīnī rejects this claim, arguing that this is the tanwin of establishment "which disappears in an annexation and remains in the absence [of annexation]" (yadhabu ma'a l-iḍafati wa-yațbutu ma'a 'adamihā). ${ }^{83}$

Al-Šrin̄in̄ notes that some grammarians add another six types of tanwīn to this list. He cites an anonymous verse that includes the entire list of ten. The additional types are: (1) redundant, (2) tanwīn al-tarannum, (3) hikāya 'verbatim quotation', (4) poetic li-

78 See, e.g., Sībawayhi, Kitāb I: 3 for a discussion of this principle. Al-'Astarābād̄ī uses this principle also to explain why nouns in the dual and the sound masculine plural do not behave as diptote, even if there are two reasons for diptosis—-see al-'Astarābādīi, Šarh I: 103.

79 See ibid.: 47.

80 Ibid.: 87. AYOUB (1991: 208) notes that in this al-’Astarābādī differed from other grammarians, who were unable to relate the distinct values of tanwin to each other and to a general property of a category of nouns. She offers a more nuanced analysis: in her view, tanwin is a marker of syntactic completeness when suffixed to a noun that functions as an argument, whereas it is a marker of syntactic incompleteness when suffixed to a noun that functions as a predicate. See AYOUB 1991: $198 \mathrm{ff}$. for a discussion.

81 CARTER 1981: 16-17 (CARTER translates these three terms, respectively, as "the tanwin of establishment", "the tanwin of stability", and "the tanwin of currency").

82 Ibid: : 18-19.

83 See ibid.: 18-21.

jis 19 (2019): 81-111 
cense, (5) metrical extravagance, (6) after hamza. ${ }^{84}$ After that he states that these types "are called tanwin in a non-literal sense, not in a literal one, since they are not peculiar to nouns" (tasmiyatuhā tanwīnan majāzun là haqūqatun li-'adami h̆tișāșihā bi-l-ismi). ${ }^{85}$ This is how al-Širbīnī reconciles between his view of tanwīn as one of the identifying features of a noun and the fact that some sources mention tanwins that can also join other parts of speech.

\section{Five types of definite article}

Ibn 'Ușfür follows his presentation of tanwìn with a categorization of functions of the definite article:

(1) li-ta'rīfi l-'ahdi fì šahșin 'aw fi jinsin 'for a definiteness [based on the addressee's] previous knowledge, of an individual or a genus' (usually, grammarians view ta'rîf al-' ahd and ta'rîf al-jins as different categories, ${ }^{86}$ but Ibn 'Ușfūr probably thinks that speakers may have previous knowledge of genera just like they may have previous knowledge of individuals, and thus these two functions of the definite article are closer to each other than to its other functions). The examples are $j \bar{a}$ an $\bar{\imath} l$-rajulu lla $\underline{d} \bar{l} j \bar{a}^{3} a k a$ 'The man that came to you came to me' (the referent of the noun prefixed by the definite article is an individual known to both the speaker and the addressee), and al-rajulu hayrun min-a l-mar'ati 'Man is better than woman' (this genus is better than that genus). ${ }^{87}$

(2) li-ta'rîfi $l$-hudūiri 'for a definiteness based on presence'. Unlike ta'rīf al-' $a h d$, which is a definiteness based on previous knowledge, this definiteness is related to the referent's being present at the moment of utterance. This is the definite article that joins the noun that follows a demonstrative pronoun, e.g., hā $\underline{d} a$ l-rajulu 'this man', or a vocative particle, e.g., yā 'ayyuhā l-rajulu 'O the man!', or 'id $\underline{d} \bar{a} l$-fujä'iyya, ${ }^{88}$ e.g., harajtu fa-'id̄a l-'asadu 'I went out and there was the lion'. This is also the definite article that appears in words such as al-'ān, al-sāc $a$, al-hīn 'now' ${ }^{89}$

(3) li-lamhi l-sifati 'because of an intimation of the adjective'. This is a definite article that is added to a proper noun that was originally an adjective, such as al-Hārit, lit. 'the plowing one' and al-'Abbās lit. 'the frowning one'. This al- is not an insepara-

84 See CARTER 1981: 20-23 for a detailed discussion.

85 Ibid.: 20-22.

86 See, e.g., GÄTJE 1970: 245. GÄTJE explains: "Die Aussonderung aus der Gattung setzt eine Verständigung ('ahd) zwischen dem Sprechenden und dem Gesprächspartner voraus. Diese erfolgt dadurch, daß das Gemeinte vorher erwähnt wird".

87 Ibn 'Ușfūr, Šarh l: 40.

88 In WRIGHT's (1967 I: 284; II: 157) words, this is an adverb "indicating something unexpected", "introducing a person or thing that comes suddenly into view".

89 Ibn 'Ușfūr, Šarh I: 40. 


\section{Beata Sheyhatovitch}

ble part of these words, as can be proven by the fact that one may say rajulun hāritun 'a plowing man' and rajulun 'abbāsun 'a frowning man' ${ }^{90}$

(4) $l i-l-\dot{g} a l a b a$ 'for a predominance'. This is a definite article that joins an indefinite noun in order to render it definite, and then dominates it. The noun consequently becomes a proper noun. For instance, al-Najm, lit. 'the star', which denotes the Pleiades; if the intended meaning is the Pleiades (and not just any star), the al- is obligatory. ${ }^{91}$

(5) $z \bar{a}^{\prime} i d a$ 'redundant'. This type of article is attached to proper nouns that do not originate in adjectives, and is used only due to poetic license. For instance:

'a-mā wa-dimā’in lā tazālu murāqatan / 'alā qunnati l-'uzzā wa-bi-l-nasri 'andamā

'I swear by blood that still penetrates / the upper part of al-'Uzzā [idol] and renders al-Nasr blood-red,92

The poet used al-Nasr instead of Nasr (lit. 'vulture'; the name of an idol worshipped by the Himyarites ${ }^{93}$ ).

After mentioning these types of $a l$ - (of which there were five), Ibn 'Ușfūr adds: "These four types are found only in nouns" (wa-hädihi al-'adrubu l-'arba'atu lā tūjadu 'illā fì l-'asmā'i hassṣatan), and then starts a discussion on al-with the meaning of allad $\bar{l}$, which joins participles, but in poetry can also join verbs and clauses. ${ }^{94}$ His mention of "four types" is truly surprising, because he clearly listed five types just before. Perhaps this is due to an attempt on his part to create a symmetry between the categorization of tanwins (five types, of which one type, tanwin al-tarannum, can join various parts of speech, and the rest can join only nouns), and the categorization of al- (again five types, of which one type can sometimes be attached to verbs and clauses, and the rest only to nouns). In defense of Ibn 'Ușfür's logic, it can only be said that the types of al- that join only nouns could be viewed as four instead of five if we ignore the "redundant" al- (which has no meaning or function besides regularizing the rhythm of a poetic verse). It is the only type in Ibn 'Ușfür's categorization which is mentioned without the preposition li- 'for', and this may mean that the author did not intend to include it in the total.

Ibn Hišām's classification of al- is completely different (which proves that Ibn 'Ușfūr's classification is by no means necessary). The former dedicates a chapter of his book to al-, which he divides into three types:

(1) A relative pronoun with the meaning of alla $\underline{d} \bar{\imath}$ and its likes, which usually joins participles. It can also join time/place expressions and nominal or verbal clauses (if the predicate is an imperfect verb). The fact that this type of al-can be attached not only

90 Ibn 'Ușfūr, Šarh I: 40.

91 Ibid:: 41. - See ShEYhATOVITCH 2018: 148-149 for a discussion of predominant proper nouns according to al-'Astarābād̄ī.

92 See Ibn 'Ușfür, Šarh I: 41, fn. 15 for a discussion of the verse's authorship and meaning. See also alBaġdādī, Hizāna VII: 214 ff. for a discussion on this verse and its context.

93 See FAHD 1993.

94 See Ibn 'Ușfūr, Šarḥ I: 41-42.

jais • 19 (2019): 81-111 
to nouns proves, according to Ibn Hišām, that it is not a definite article (harf alta $\left.^{\mathrm{c}} \mathrm{i} f\right)^{95}$

(2) A definite article, of which there are two types, (a) 'ahdiyya 'based on previous knowledge' and (b) jinsiyya 'generic' ${ }^{96}$ Each of these two types is, in its turn, divided into three subtypes: ${ }^{97}$

(a) 'ahdiyya

(i) "The [referent of] the noun related to it is known because [that noun] was mentioned before" (yakūnu mașhūbuhā ma'hüdan dikriyyan), e.g., Q 73:15-16 kamā 'arsalnā 'ilā fir'awna rasūlan fa-'așā fir'awnu l-rasūla 'as We sent to Pharaoh a Messenger, but Pharaoh rebelled against the Messenger'. ${ }^{98}$ The definite article in al-rasūl signifies that the word's referent is the same as of the previously-mentioned rasūl. Gabučan notes that this description corresponds to the European notion of "anaphoric article". ${ }^{99}$

(ii) "[The referent of the noun related to it] is known, because it is present in the [addressee's] mind" (ma'hūdan dihniyyan), e.g., Q 9:40 'id humā fi $l$-g $\bar{a} r i$ 'when the two were in the Cave'. ${ }^{100}$ Interestingly, this is the first time "the cave" is mentioned in the sūrah; Ibn Hišām considers its referent as "present in the [addressee's] mind", because the Muslim tradition links it to a specific event when Muhammad and 'Abū Bakr were hiding in a cave near Mecca, and their enemies were not able to find them. $^{101}$

(iii) "[The referent of the noun related to it] is known, because it is present [in the speech situation]" (ma'hūdan ḥudūriyyan]. Here Ibn Hišām cites Ibn 'Ușfür's description of cases that the latter classifies as li-ta'rîf al$h u d \bar{u} r$ (the second item in Ibn 'Ușfür's classification mentioned above). This proves that Ibn Hišām was acquainted with Ibn 'Ușfūr's work, and supports an assumption that his classification of al- is a reformulation of the latter's.

Ibn Hišām criticizes some points in Ibn 'Ușfūr's description. First, when the sentence lā taštum-i l-rajula 'Do not curse the man!' is produced by a speaker who witnesses someone cursing a third party, the word alrajul is definite because its referent is present in the speech situation (a case which Ibn 'Ușfür did not mention). Additionally, al- that follows

95 See Ibn Hišām, Muginni I: 60-61.

96 LARCHER (1991: 146) translates 'ahdiyya as "thématique", and jinsiyya as "générique".

97 See GABUČAN 1972: 46-47 for a discussion of this excerpt.

98 Ibn Hišām, Muginn̄ l: 61.

99 GABUČAN 1972: 46.

100 Ibn Hišām, Muginnı̀ 61.

101 See, e.g.,; al-Zamahšarī, Kǎ̌šăfı: 259-260; al-Ṭabrisī, Majma` al-Bayān V: 41. 


\section{Beata Sheyhatovitch}

'idā l-fujä'iyya "does not signify the definiteness of a thing present at the speech situation, nor a definiteness that resembles [a definiteness of a thing] present at the speech situation" (laysa li-ta'rîfi šay'in häạdirin hâlata l-takallumi fa-lā tušbihu mā l-kalāmu fìhi). ${ }^{102}$ This criticism is based on the fact that the thing mentioned after 'id $\mathbf{d} l$-fujäiyya is present at the situation presented in the sentence (which may be different from the speech situation ${ }^{103}$ ). However, Ibn 'Ușfür does not mention the speech situation in his discussion, mentioning only the idea of presence (which is relevant in the case of 'id̄a l-fujä'iyya) — thus, Ibn Hišām's criticism does not seem justified.

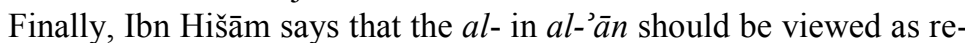
dundant $\left(z \bar{a}^{\prime} i d a\right)$ rather than as definite article. That is because this alis an inseparable part of the word, whereas the definite article is not known to appear as an inseparable part of the word. ${ }^{104}$

(b) jinsiyya: ${ }^{105}$

(i) "Signifying [that the word] comprises all the individuals [that can be referred by it]" (li-stigrāqi l-'afrädi). This is the al- "that can be replaced by kull in its literal sense" (allatī tahlufuhā kullun haqīqatan). For instance, Q 4:28 wa-h̆uliqa l-'insānu ḍa '̄ fan 'for man was created a weakling'. ${ }^{106}$ According to the principle formulated by Ibn Hišām, al-'insān is definite in a generic, inclusive definiteness, which can be demonstrated by replacing it by the phrase kullu 'insānin in its literal sense.

(ii) "Signifying [that the word's referent] comprises all the exclusive attributes of individuals [that can be referred to by the word]" (li-stigrāqi hașā'iși al-'afrādi). This is the al- "that can be replaced by kull in its non-literal sense" (allatī tahlufuhā kullun majāzan). For instance, zaydun-i l-rajulu 'ilman 'Zayd is the man in terms of knowledge'. ${ }^{107}$ This sentence can be paraphrased by zaydun kullu rajulin 'ilman 'Zayd equals all men in terms of knowledge', i.e., Zayd's knowledge is perfect. $^{108}$

\footnotetext{
102 Ibn Hišām, Muginnı I: 61.

103 'I $\underline{d} \bar{a} l$-fujäiyya refers to the same time as the preceding statement. See the examples in WRIGHT 1967 I: 284; II: $157-158$.

104 Ibn Hišām, Muginn̄ l: 61.

105 See GABUČAN 1972: 48-50 for a discussion on generic definiteness according to Ibn Hišām and additional grammarians.

106 Ibn Hišām, Muġnı̄ I: 61 .

107 Ibid.

108 These are probably the cases described by GÄTJE (1970: 249-250) as "die generelle Determination, wenn sie beim Individuum steht, um zu zeigen, daß dieses die Merkmale der Gattung in vollem Umfange aufweist".
}

jais • 19 (2019): 81-111 
(iii) "That renders the essence definite" (li-ta'rîfi l-māhiyyati). This al- cannot be replaced by $k u l l$, in either its literal or its non-literal sense. For instance, if someone says wa-llāhi lā 'atazawwaju l-nisă’a 'By God, I will not marry the women', his vow would be violated if he married even a single woman. ${ }^{109}$

(3) $z \bar{a}$ 'ida 'redundant':

(a) "[that constitutes] an inseparable part [of the noun]" (läzima). That is the alof relative pronouns, according to the view whereby they are rendered definite by the relative clause, ${ }^{110}$ and of proper nouns, "provided that [al-] joined them when they were transmitted (from their original meaning to functioning as proper nouns)" (bi-šarți muqāranatihā li-naqliha ${ }^{-11}$ ), which is the case with al-Nașr, al-Na'mān, al-Lāt, al-'Uzzā, or "when they were invented" (lirtijālihā), which is the case with al-Samaw'al, or when "the word became dominant [in referring to] one of its original referents" (li-galabatihā 'ala ba'di man hiya lahu fi l-'așli), which is the case with al-Bayt, lit. 'The House' (referring to the Ka'ba), al-Madīna, lit. 'The City' (referring to al-Ṭayyiba 'The Good', the city in Saudi Arabia), and al-Najm, lit. 'The Star' (referring to the Pleiades). ${ }^{112}$

This last case of "redundant inseparable al-" corresponds to the fourth item in Ibn 'Ușfūr's classification. ${ }^{113}$

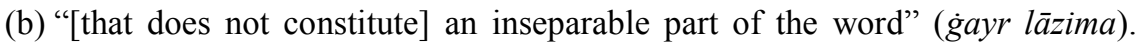
This category is divided into two types:

(i) A common type, that appears in eloquent speech. This is the al- that appears in proper nouns "that were transferred from [common nouns] without [al-] that can be prefixed by it, is such a way that [a proper noun includes] an intimation [of the original common noun]" (manqūl min mujarrad șâlih lahā malmūh 'aṣluhu). This is the case, e.g., of al-Hārit, lit. 'the plowing one', al-'Abbās 'the frowning one', and al-Dahhāk 'the one who laughs frequently'. ${ }^{114}$

(ii) An uncommon type of $a l$-, which may appear in poetry and in anomalous instances of prose. ${ }^{115}$

\footnotetext{
109 Ibn Hišām, Muginī l: 61-62.

110 See Section 3 above for a discussion on the status of relative pronouns. Ibn Hišăm cites the view rejected by al-'Astarābādīi-see pp. 86-87 above.

111 LARCHER (1992: 358-359) translates manqūla (a passive participle derived from the same root as naql, that refers to a change in a constituent's function) as "tranférées".

112 Ibn Hišām, Muġnī l: 62.

113 See p. 93-94 above for a discussion.

114 Ibn Hišām, Muginnı I: 63.

115 See ibid: : 63-64 for examples.
} 


\section{The five types of tawābic}

Tawābic (sing. $t \bar{a} b i$ ) is a category of words "whose case assignment is caused by their 'following' another word". This category created a special problem for the Arab grammarians, as its case assignment cannot be explained by governance. ${ }^{116}$

Síbawayhi does not speak of such a category. Al-Mubarrad in his treatise uses various terms related to this category, without however systematizing them. ${ }^{117}$ Ibn al-Sarrāj is probably the first one to speak of tawābic as a category, that comprises five types of sentence constituents:

(1) Tawkid 'emphasizer'. This type is divided into two:

(a) "emphasis by repetition of the noun" (tawkìd bi-takrīr al-ism):

(i) “A type in which a noun is repeated literally" (darb yu'ā du fíhi lismu bi-lafẓihi). Despite this formulation, Ibn al-Sarrāj demonstrates that constituents that are repeated can be nouns, verbs, particles (together with the nouns that receive jarr from them) and even clauses. ${ }^{118}$ Perhaps he uses the term ism here, although he has in mind various types of constituents, because of the principle that any word can be viewed as a noun, if it is produced with the linguistic expression itself in mind (rather than its meaning/referent). ${ }^{11}$

(ii) "[A type in which] the meaning is repeated in different words" ('íädat al-ma'nā bi-lafžin 'ähara). For instance, marartu bi-zaydin $n a f s i h i$ 'I passed by Zayd himself'. ${ }^{120}$

(b) "signifying comprehensiveness and generality" (li-l-'iḥạta wa-l-'umūm). Ibn al-Sarrāj has in mind the derivatives of words such as kull, 'ajma', 'akta' 'all', and also kilä/kiltā 'both (masc./fem.)', talätatuhum 'the three of them', etc. ${ }^{121}$

116 See the discussions of tawābic in CARTER 1981: 148-149, $238 \mathrm{ff}$. (where the term is translated as “concordants"), OWENS 1988: 57-58, $162 \mathrm{ff}$. (where the term is translated as “modifiers"), VERSTEEGH 2009: 221. As for the governor of tawābic, Ibn al-'Anbārī ('Asrār, 294-295) presents two views regarding the governor of an adjectival qualifier: Sïbawayhi's view, that its governor is the same as the head's, and 'Abū Hasan al-'Ahfaš's, that the qualifier's raf' is assigned by its being a tābic of a head in raf' etc. Ibn al-'Anbārī notes that the former view is more widely accepted (see LEVIN 1995: 215 for a discussion of additional sources that mention the latter view).

117 For instance, while discussing the structure yā nașru nașrun nașran he uses the terms badal, bayān (which probably corresponds to 'atf bayān), and ma'tūf (see al-Mubarrad, Muqtạ̣ab IV: 210-211); while discussing the structure $y \bar{a} h \bar{a} \underline{d} \bar{a}$ l-țawìlu 'O this tall one!' he explains that al-țawil is 'atf bayān rather than na't (see ibid.: 220).

118 See Ibn al-Sarrāj, 'Ușūl ı: 406 for examples.

119 See SHEYHATOVITCH 2018: 53-54 for a discussion of this principle according to al-'Astarābād̄ī.

120 See Ibn al-Sarrāj, 'Ușūl ı: 406-407 for additional examples.

121 Ibid:: 407.

jais 19 (2019): 81-111 
(2) $N a^{\prime} t$ 'adjectival qualifier'. Interestingly, Ibn al-Sarrāj distinguishes five types of it (and thus creates a fivefold division inside another fivefold division, proving his interest in this number):

(a) "An attribute [related to the appearance ${ }^{122}$ ] of the described thing, which may exist in [that thing] or in something related to it logically" (mā kāna hilyatan li-l-mawșüfi takūnu fïhi 'aw fí šay'in min sababihi). ${ }^{123}$ The examples for the first option are: marartu bi-rajulin 'azraqa/'aḥmara/țawìlin/qașīin 'I passed by a blue/red/tall/short man'; the examples for the second option are: marartu bi-rajulin hasanin 'abühu 'I passed by a man whose father is good' and madaytu 'ilä rajulin tawīlin 'ahūhu 'I went to a man whose brother is tall'. ${ }^{124}$

(b) "An action of the described thing, which may be performed by [the latter] or by something related to it logically" (mā kāna fi lan li-l-mawșüfi yakūnu bihi fä́ilan 'aw muttașilan bi-šay'in min sababihi). The examples for the former option are: marartu bi-rajulin qä imin/nä̉imin/dâaribin 'I passed by a standing/sleeping/hitting man'; the examples for the latter option are marartu birajulin d़̄ribin 'abūhu 'I passed by a man whose father is hitting', marartu bi-rajulin qäimin 'ahūhu 'I passed by a man whose brother is standing', ra'aytu rajulan d̦āriban 'ahūhu 'amran "I saw a man whose brother is hitting 'Amr', etc. ${ }^{125}$

(c) "An attribute [of the described thing], that is neither [its] action nor is related to its appearance" (mā kāna șifatan gayra 'amalin wa-tahliyatin), e.g., marartu bi-rajulin 'ālimin/'āqilin 'I passed by a knowledgeable/reasonable man', marartu bi-rajulin 'ālimin 'abūhu 'I passed by a man whose father is knowledgeable', marartu bi-rajulin zarïfatin jāriyatuhu 'I passed by a man whose female slave is charming'.

(d) "Relation" (nasab). These are adjectives that relate a person or thing to a father, a place, a profession, or some category. For instance marartu bi-rajulin hāšimiyyin/'arabiyyin 'I passed by a Hāšimī/Bedouin man' (with adjectives that relate the man to certain genera), marartu bi-rajulin bazzāzin/'atțārin/ najjārin "I passed by a man who is a seller of cloth/a seller of perfumes/a carpenter' (with adjectives that relate the man to things with which he deals),

122 This addition is based on one of the definitions of hilya given in LANE (1865 II: 635): "the appearance in respect of colour, or complexion, \&c., of a man". The addition seems necessary, in order to highlight the difference between this type of qualifier and type (c), that includes attributes which have no external manifestation (see below)

123 See the discussion of the term sabab in CARTER 2009.

124 Ibn al-Sarrāj, 'Usūul I: 409-410. Such constructions are known as na't sababì, an adjective that refers to the main noun "in virtue of a following word which is connected with it". See WRIGHT 1967 II: 283284. DIEM (1998: 12) renders na't sababī as "adjektivischer Satz" since, on the one hand, it is equivalent to a sentence, and on the other hand it has the same syntactic distribution as adjectives and participles. See DIEM 1998 for a detailed discussion on the uses of na't sababī.

125 See Ibn al-Sarrāj, 'Ușūl l: 410-411 for additional discussion and examples. 


\section{Beata Sheyhatovitch}

marartu bi-rajulin bașriyyin/miṣriyyin/kūfiyyin 'I passed by a Bașran/Egyptian/Küfan man' (with adjectives that relate the man to places). ${ }^{126}$

(e) "Describing [things] by means of $\underline{d} \bar{u}$ 'possessor"” (al-was $f$ bi- $\underline{d} \bar{\imath})$. For instance, marartu bi-rajulin $\underline{d} \bar{\imath}$ 'iblin 'I passed by a man who possesses camels', marartu bi-rajulin $\underline{\underline{ }} \bar{\imath}$ 'adabin 'I passed by a man who possesses manners', marartu bi-rajulin $\underline{d} \bar{l}$ 'aqlin 'I passed by a man who possesses reason'. ${ }^{127}$

This classification seems somewhat artificial, especially the distinction between (a) and (c), and may serve as yet another proof of Ibn al-Sarrāj's adherence to the number 'five' (which is also apparent from the examples surveyed by Okazaki). ${ }^{128}$

(3) 'Atf al-bayān 'the explicative'. Ibn al-Sarrāj explains that the difference between this constituent and an adjectival qualifier is that the former is an underived noun. The grammarians avoid calling it an adjectival qualifier, because it does not signify an attribute of the described thing and does not correspond to any type of qualifier. It is called 'the explicative' because it distinguishes between the referent of its head and other objects with the same name. For instance: ra'aytu zaydan 'abā 'amrin 'I saw Zayd, 'Amr's father' and laqītu 'ahāka bakran 'I met your brother Bakr'. ${ }^{129}$

The difference between 'atf al-bayān and apposition is that the former is intended to be similar to an adjectival qualifier of the head, and the latter is intended to be a constituent that can replace the head. Thus, when the speaker uses 'atf al-bayān, he says $y \bar{a}$ 'ahānā zaydan 'O our brother Zayd!'130 (zaydan takes nașb, according to the basic rule regarding words in vocative ${ }^{131}$ ), and when he uses apposition, he says $y \bar{a}$ 'ahānā zaydu (zaydu takes damma, as a single noun that follows a vocative particle, as if it followed $y \bar{a}$ directly). ${ }^{132}$

(4) 'Atf al-badal 'apposition'. Ibn al-Sarrāj recognizes four types of apposition. ${ }^{133}$

126 See Ibn al-Sarrāj, 'Ușūl l: 411-412.

127 See ibid.: 412. It is interesting to compare this categorization of adjectival qualifiers' functions with Sībawayhi's three types of șifa: hilya, qarāba and mubham (the relevant passages from al-Kitāb are analyzed in TALMON 1981: 286).

128 According to OKAZAKI 2003: 18-20, Ibn al-Sarrāj was the first grammarian to explicitly distinguish between five categories of $m a f^{f} \bar{u} l$ and five categories of al-mušabbah bi-l-maf ${ }^{f} \bar{u} l$. See ibid.: 22 for a discussion of other fivefold categorizations in al-'Ușūl.

129 See Ibn al-Sarrāj, 'Ușūl l: 432.

130 Ibid

131 According to Ibn al-Sarrāj, the vocative particle $y \bar{a}$ governs the following noun phrase similarly to the verb 'unād $\bar{\imath}$ 'I call'. However, a definite single noun takes the bina $\bar{a}$ ' ending damma, because such a noun occurs in a position characteristic of personal pronouns (since it denotes a second person instead of its regular meaning). See the discussion in ibid: 300 .

132 Ibn al-Sarrāj, 'Ușūl I: 432. This passage is also discussed in SARTORI, forthcoming: Section 1.2. In SARTORI's (forthcoming: Section 1.1) words, " atf bayān represents in fact an intersection between șifa and badal", as it shares some characteristics with both of them; thus, the grammarians make efforts to clarify how 'atf bayān is different.

133 See Ibn al-Sarrāj, 'Ușūl l: 432-435 for a discussion. See also ESSEESY 2006 and SARTORI, forthcoming: Section 1.1 for a discussion on various types of apposition recognized by Arab grammarians. 
(5) Al-'atf bi-l-harf 'coordination by means of a particle'. Ibn al-Sarrāj states that there are ten coordinative particles that "make the constituent that follows them to agree [in case] with the noun or verb that precedes them" (yutbicna mä ba'dahunna ma qablahunna min-a l-'asmä'i wa-l-'af'äli). ${ }^{134}$

Ibn Jinnī mentions the same five types of tawābici, ${ }^{135}$ Ibn al-'Anbārī does not speak explicitly of tawābic as a category, but places in a succession the chapters dealing with tawkīd, was $f$ (a term very close to $n a^{\prime} t$ ), 'atf al-bayān, badal, and 'atf. . $^{136}$

Al-Zajjājī appears to be the first grammarian who speaks about four tawābic: al-na't, al-'atf, al-tawkìd, al-badal (he omits 'atf al-bayān). ${ }^{137}$ Ibn 'Ușfūr does not challenge this categorization, but incorporates 'atf al-bayān by distinguishing between two types of 'atf: 'atf al-bayān and 'atf al-nasq 'coordination'. ${ }^{138}$ Al-Bațalyawsī (d. 1127) openly criticizes al-Zajjājī's categorization of tawābi': he says that al-Zajjājī did not mention 'atf al-bayān, as if it can be included in his four categories, which is not true. Al-Bațalyawsī notes that it exists only in definite nouns, and shares some positions with the adjectival qualifier, some with apposition, and some are unique to it (which last point proves that al-Zajjājī's categorization is not accurate). ${ }^{139} \mathrm{He}$ mentions three positions that are unique to catf albayān:

1. In vocative constructions:

'inn̄̄ wa-'astāârin suṭirna sațran / la-qā̉ilun yā nașru naṣrun naṣrā

'I swear by the lines [of the Qur'ān] that are indeed written, / I say: O Nașr, Nașr, Nașr..., 140

Al-Bațalyawsī explains that those who assign nașb to the second and third nașr, construe them as 'atf al-bayān that agrees with the position of the first nașr, which follows a vocative particle ${ }^{141}$ (because the position following a vocative particle should in principle be occupied by a noun in $n a s, b$; however, a semantically definite noun that is not an annexed element takes a bina $\bar{a}^{\text {ending }}$ damma in this position ${ }^{142}$ ). Those who

134 Ibn al-Sarrāj, 'Ușūl l: 442. See ibid.: 442-446 for a detailed discussion of all coordinative particles.

135 Ibn Jinnī, Luma', 138.

136 Ibn al-'Anbārī, 'Asrār, 283-306. See also Ibn Ya ī̌š, Šarh III: 38-39 for a similar discussion.

137 Al-Zajjàjīi, Jumal, 26.

138 Ibn 'Ușfür, Šarh I: 174. See ibid:: 268-272 for a detailed discussion of 'atf al-bayān. This is also the solution of Ibn 'Aqīl in dealing with Ibn Mālik's fourfold categorization of tawābic: he incorporates 'atf albayān into Ibn Mālik's model (presented in Ibn 'Aqīl, Šarh III: 190) by distinguishing between two types of 'atf — see ibid:: 218. See ibid.: 218-223 for a further discussion of 'atf al-bayān. Al-Širbīnīs presentation is the same: he first speaks of four types of tawābic (CARTER 1981: 148), and then distinguishes between two types of 'atf (see ibid.: 274). TALMON (1981: 288) notes that the literal meaning of 'atf"turning s.o. or s.th. (to)" - allows its application to both "conjunctive" and "appositival" categories.

139 Al-Bațalyawsī, Hulal, 104.

140 This is a verse by Ru’ba ibn al-'Ajjāj (d. 762). The Nașr who is addressed here is Nașr ibn Sayyār (the last Umayyad governor of Hurāsān, d. 748). See HeINRICHS 1995. See also al-Bag̉dādī, Hizāna ll: 219-224.

141 Al-Bațalyawsī, Hulal, 105.

142 See fn. 131 above. 


\section{Beata Sheyhatovitch}

assign raf'+tanwīn to the second nașr, construe it as 'atf al-bayān that agrees with the form of the first one (which is possible, because the damma in the ending of a noun that follows a vocative particle resembles an ' $i$ ' $r \bar{a} b$ ending ${ }^{143}$ ), and construe the third $n a s ̦ r$ as 'atf al-bayān that agrees with the position of the first one. Those who assign the second nașr raf ${ }^{c}$ without a tanwinn, construe it as an apposition of the first. ${ }^{144}$ As we shall see below, al-Bațalyawsī holds that in apposition there is the intention of repeating the governor, whereas there is no such intention in 'atf al-bayān. Thus, one can imagine the second nașr as immediately following a suppressed vocative particle, and consequently assign it damma, provided one construes the second nașr as an apposition.

2. With vague constituents (i.e., demonstrative pronouns): e.g., marartu bi-hāa $\bar{a}$ l-rajuli 'I passed by this man', laqītu hā that grammarians refer to nouns following the demonstrative as $n a^{c} t$ 'adjectival qualifier', whereas it is actually 'atf bayān .

3. With active participles: e.g., hā $\underline{d} \bar{a}$ l-dāribu l-rajuli zaydin 'This is the one hitting the man, Zayd'. Zayd can be assigned jarr only if it is construed as 'atf al-bayān of alrajul. In order to be construed as an apposition, it should be a word that can occupy the position of its head, whereas one cannot say *hāda l-darribu zaydin 'This is the one hitting Zayd' (instead one should say hād $\bar{a}$ l-ḍâribu zaydan, i.e., use a direct object instead of an annexation structure), because a noun prefixed by the definite article cannot be annexed to a noun that is not prefixed by that article, unless the former noun is in dual or masculine sound plural form. ${ }^{145}$

After that, al-Bațalyawsī takes pains to distinguish between 'atf al-bayān and other tawābic that can be confused with it. He mentions five points of difference between 'atf al-bayān and adjectival qualifiers:

1. The function of a qualifier is usually performed by adjectives, whereas 'atf al-bayān is an underived noun, similarly to apposition. ${ }^{146}$

2. A qualifier may be either definite or indefinite, whereas 'atf al-bayān, according to the Bașran view, must be definite. ${ }^{147}$

143 See ShEYHATOVITCH 2018: 107-109 for a detailed discussion of this point according to al-'Astarābād̄i.

144 Al-Bațalyawsī, Hulal, 105.

145 Ibid.: 106. - According to al-Zamahšarī (Ibn Ya Y̌šs̆ Šarh II: 122), one can say humā l-ḍāribā zaydin 'The two of them are the ones hitting Zayd', and hum-u l-dāribu zaydin 'They are the ones hitting Zayd', but not *al-dāribu zaydin 'the one hitting Zayd', because in this case the annexation does not achieve 'lightness'. Ibn Ya 'ĩ̌ explains that $a l$ - that joins an active participle has the meaning of a relative pronoun, thus the participle in this position is equivalent to a verb, and should govern the following word. If the participle is in the dual or sound masculine plural form, this principle may be breached for the sake of lightness (which is achieved by omitting the ninn of the dual/ sound masculine plural in an annexation); however, principles should not be breached if that brings no benefit. Al-dāaribu l-rajuli 'the one hitting the man' is acceptable (unlike *al-dāribu zaydin), since this phrase behaves analogously to al-hasanu $l$-wajhi 'the one whose face is beautiful'. See Ibn Ya '`̃̌s, Šarh II: 122-123 for a detailed discussion.

146 Al-Bațalyawsī, Hulal, 108.

jais • 19 (2019): 81-111 
3. "A qualifier may [signify an attribute of the referent] of the head noun or of something related to it logically" ('anna l-na'ta yakūnu bi-mā huwa min-a l-man'ūti wabi-mā huwa min sababihi), whereas 'atf al-bayān is co-referential with its head.

4. A qualifier may be replaced by clauses, time/place expressions and constituents in jarr, and this does not occur with 'atf al-bayān.

5. A qualifier signifies some part of the head noun's referent, namely, some attribute of it, whereas 'atf al-bayān is co-referential with its head. ${ }^{148}$

According to al-Bațalyawsī, there are four points of difference between 'aț al-bayān and apposition:

1. An apposition may be co-referential with its head, and may also signify a part of the head's referent or a thing that accompanies the head's referent and is included in it, e.g., suliba zaydun tawbuhu 'Zayd was robbed, his garment'. ${ }^{149}$ An apposition may signify an action of the referent of its head or an accident related to it, whereas 'atf al-bayān must be co-referential with its head.

2. The function of apposition may be performed by both definite and indefinite nouns, and by both explicit nouns and pronouns, whereas 'atf al-bayān, according to the Bașran view, must be a definite explicit noun.

3. In the case of apposition "there is the intention ${ }^{150}$ of repeating the governor" (yuqaddaru ma'ahu 'i'ädatu l-'ámili), as if a new sentence is started, whereas in the case of 'atf al-bayān there is no such intention; the latter resembles in this respect an adjectival qualifier.

4. "There is a type of apposition that is related to mistakes" ('anna l-badala yaj $\vec{\imath} u$ minhu mā jarā majrā l-galați), ${ }^{151}$ whereas there is no such thing in 'atf al-bayān. ${ }^{152}$

This notwithstanding, al-'Astarābād̄̄ī states:

Until now I have not revealed a clear difference between a full substitution and 'atf al-bayān. Moreover, I hold that 'atf al-bayān is actually an apposition (wa-'anā 'ilā

147 Al-Bațalyawsī, Hulal, 109. Al-Bațalyawsī refers here specifically to the Bașran view, since the Küfan grammarians held that 'atf al-bayān is indefinite, if it follows an indefinite head. In contrast, the Bașran grammarians maintained that 'atf al-bayān must be a definite noun that follows a definite head, and regarded cases of indefinite nouns following an indefinite head as apposition. See the discussion in 'Abū Ḥayyān, Baḥr III: 10.

148 Al-Bațalyawsī, Hulal, 109.

149 Here reference is made to the three main types of apposition distinguished by the Arab grammarians: badal kull min kull 'full substitution', badal ba'd min kull 'permutative apposition', and badal ištimāl 'substitution of inclusiveness'. See ESSEESY 2006: 124 for a discussion.

150 See LEVIN 1997: 151-157 for a discussion on taqdī in the sense of 'speaker's intention'.

151 Here al-Bațalyawsī has in mind badal al-galat 'permutative of error', where the speaker self-corrects what he or she has stated. For instance, ra'aytu rajulan himāran 'I saw a man, [rather,] a donkey'. ESSEESY 2006: 124.

152 Al-Bațalyawsī, Hulal, 109. Interestingly, Ibn Hišām mentions eight points of difference between 'atf al-bayān and apposition. See Ibn Hišām, Muginn̄, 525-529. 
l-'āna lam yazhar lī farqun jaliyyun bayna badali l-kulli min-a l-kulli wa-'atfi lbayāni, bal lā' 'arā 'atfa l-bayāni 'illā l-badala). ${ }^{153}$

Al-'Astarābādī argues that Sībawayhi held the same view when he said, with regard to the sentence marartu bi-rajulin 'abdi llāhi 'I passed by a man, 'Abdallāh', that there is a substitution of a definite noun for an indefinite one, as if the speaker was asked 'Who did you pass by?', or thought that someone might ask such a question, and thus replaced the indefinite noun with a more definite one. ${ }^{154}$

It should be mentioned that al-'Astarābādī equates 'atf al-bayān with a full substitution, one of the apposition types - therefore, points (1) and (4) from al-Batalyawsī’s discussion on the difference between 'atf al-bayān and apposition, in which various types of the latter are mentioned, should be irrelevant for him.

Al-'Astarābādī says that other grammarians may claim that the difference between 'atf al-bayān and apposition is that an apposition (and not its head) is "the one intended in the ascription" (al-maqșūd bi-l-nisba), whereas 'atf al-bayān is an explanation, and an explanation is secondary in relation to what is explained. Therefore, in the case of 'atf al-bayan the one intended in the ascription is the head. ${ }^{155}$ The term nisba in Šarh al-Käfiya refers to semantic relations between constituents, which may be predicative or not. ${ }^{156}$ When al'Astarābādī speaks of "being intended in the ascription", he probably means that the constituent in question is more important than another one or other ones, it is the one that is really meant to create syntactic connections with other parts of the sentence. ${ }^{157}$ The grammarians' claim that the apposition is more important than its head (whereas in the case of adjectival qualifier the head is more important) is well known. ${ }^{158}$

Al-'Astarābādī does not accept the claim that in the case of an apposition the speaker intends the second constituent only; in his view, this is true only for 'permutative of error', in which "the second constituent (i.e., the apposition) is obviously intended instead of the first (i.e., the head)" (fa-'inna kawna l-tān̄i fìhi huwa l-maqșūdu dūna l-'awwali ẓāhirun). ${ }^{159} \mathrm{He}$

153 Al-'Astarābādīi, Šarh II: 379. See SARTORI, forthcoming: Section 1 for an alternative translation of this passage.

154 Al-'Astarābād̄ī, Šarh II: 379. Here al-'Astarābād̄ī refers to a discussion from Sībawayhi, Kitāb I: 192. However, Sībawayhi did use the term 'atf al-bayān once-while discussing the above-mentioned verse by Ru'ba (see Kitāb I: 263). See TALMON 1981: 282 for a discussion of a relevant excerpt. TALMON (1981) reconstructs the category of "appositival 'atf" in Sỉbawayhi's al-Kitäb, considering it an important syntactic innovation that can be attributed without doubt to Sībawayhi and al-Halīl, in contrast to grammarians of Sībawayhi's time and of previous generations. According to Talmon's description, Sībawayhi's "appositival 'atf' roughly corresponds to both tawkīd and 'atf bayān in later grammatical literature.

155 Al-'Astarābāđ̄ī, Šarh II: 380

156 See Sheyhatovitch 2018: 42-51 for a discussion.

157 See ibid.: 142, fn. 66 for a discussion of an excerpt from Ibn al-H̄ājib’s Šarh al-Käfiya, where the head of an adjectival qualifier is presented as "the one intended in the informative ascription".

158 For instance, al-Jurjān̄̄ (Muqtașid II: 930) says: "The apposition behaves as if the governor was repeated before it, because the head is neglected for the sake of the apposition" (wa-'innamā kāna l-badalu fi hukmi takrīri l-'āmili li-'ajli 'anna l-badala yutraku 'ilayhi l-mubdalu minhu). See SARTORI, forthcoming for a discussion on this and similar excerpts.

159 Al-'Astarābād̄ī, Šarḥ ॥l: 380

ز 19 (2019): 81-111 
explains his position by recalling that in three types of apposition ${ }^{160}$ the head overtly functions as "[a constituent] to which something is ascribed" (mansūb 'ilayhi). Thus, its mention should create "an (additional) meaning" ( $\left.f \vec{a}^{\prime} i d a\right)^{161}$ that would not have been achieved without itbecause the speech of eloquent people (let alone God and his Prophet) should not include useless elements. ${ }^{162}$ Given that the head noun is the one to which something else is overtly ascribed, and that it includes a meaning that justifies other constituents being ascribed to it, it would be inconsistent with the overt structure to claim that it is not intended. ${ }^{163}$

After that, al-'Astarābādī explains the three possible semantic contributions that may be achieved by the combination of the head noun and full substitution. His conclusion is that 'atf al-bayān is a name for a full substitution in which the second constituent clarifies the head. ${ }^{164}$ In other words, he views 'atf al-bayān as a sub-type of apposition (i.e., a type of full substitution, which, in its turn, is a type of apposition).

Al-'Astarābād̄ī mentions the claim that apposition (unlike 'atf al-bayānn) "[behaves] as if the governor was repeated" ( $f i$ h hukmi takrīri l-'ämili; this claim corresponds to item (3) in al-Batalyawsī's above-mentioned presentation of points of difference between 'atf al-bayān and apposition). ${ }^{165}$ His response is: even if this claim could be accepted in cases where the governor is overtly repeated, how could the addressee know that (i.e., that there is an intention to repeat the governor) in cases where it is not repeated? Moreover, if the claim of repeating the governor is accepted in the case of apposition, it should be accepted in the case of 'atf al-bayān as well. ${ }^{166}$ After that al-'Astarābādī mentions the claim of some grammarians that 'atf al-bayān, unlike apposition, must agree with the head noun in definiteness. ${ }^{167}$ This claim roughly corresponds to item (2) in al-Batalyawsī's presentation: ${ }^{168}$ given the fact that most grammarians hold that 'atf al-bayān follows only definite nouns, saying that it must agree with its head is equivalent to saying that it must be definite. Al-

160 I.e., the types mentioned in fn. 149 above.

161 This use of the term $f \bar{a}$ 'ida corresponds to " $f \bar{a}$ id $a$ as an addition to the message", one of the meanings of the term distinguished in SHEYHATOVITCH 2012.

162 Al-’Astarābād̄ī, Šarh II: 380. See SHEYHATOVITCH 2019a: 284 for a discussion of another application of this principle in al-'Astarābādī's Šarḥ al-Käfiya.

163 Al-’Astarābād̄ī, Šarh II: 380 .

164 Ibid: : 380-381. See SHEYHATOVITCH 2019b: Section 4 for a discussion of two possible types of 'atf bayān according to al-'Astarābād̄i (interestingly, the number 'five' plays an important role in the presentation of the second type).

165 See p. 103 above. See SARTORI, forthcoming, for a survey of other sources who view "the repetition of the governor" as a distinguishing characteristic of apposition.

166 Al-’Astarābād̄ī, Šarh II: 383. Al-'Astarābād̄i believes that the governor should be the same in all tawābic (see ibid.: 279-282 for a discussion), whereas other grammarians did not necessarily hold the same view. For instance, Ibn al-'Anbārī maintains that the governor of the adjectival qualifier is the same as the governor of the head (see fn. 116 above), whereas the governor of the apposition "is not the same as the governor of the head, and [the head and the apposition are in] two [sentences]" (gayru l-'àmili fi l-mubdali, wa-huwa jumlatāni). He notes that most grammarians held this view. See Ibn al'Anbārī, 'Asrār, 300-301.

167 Al-'Astarābād̄ī, Šarh II: 383.

168 See p. 103 above. 
'Astarābādī says in response that "a constituent that is called 'atf al-bayān" (al-musammā 'atfa bayānin; a formulation that stresses again his disapproval of this term) can also disagree with its head in definiteness. ${ }^{169}$

Sartori, after analyzing various grammarians' remarks on the difference between the 'atf al-bayān and apposition, reaches the conclusion that the most essential difference is of a suprasegmental character, namely, apposition is preceded in speech by a pause, whereas 'atf albayān is pronounced immediately after the main noun, similarly to an adjectival qualifier. ${ }^{170}$

It is unclear whether al-'Astarābād̄i did not grasp this essential difference between 'atf al-bayān and apposition, or did grasp it but considered it not significant enough to categorize these two as separate types of tawābic. He repeats his statement that 'atf al-bayān is actually an apposition several times, ${ }^{171}$ but, this notwithstanding, constantly speaks of five tawa $\bar{a} i^{{ }^{1}}{ }^{172}$ That can be explained either by retaining the accepted views and terminology, or by recognizing the importance of the number 'five' (the former possibility seems less convincing, given al-'Astarābād̄ì's general non-conformism ${ }^{173}$ ).

Interestingly enough, the tendency towards a division into four (instead of five) types of tawābic, that started with al-Zajjājī and Ibn Mālik, became dominant in modern grammatical literature in Arabic. For instance, Hasan in his al-Naḥw al-Wäfl dedicates a detailed chapter to "the four tawābi", in which 'atf al-bayān is subsumed under the category of 'atf. ${ }^{174}$

\section{Conclusion}

This article analyzed several fivefold divisions found in medieval Arabic grammatical literature. It strove to determine to what extent these divisions are theoretically justified and to what extent 'five' appears in them as a typological number (given the special place of this number in Islam).

The first categorization that was discussed was "five types of meaningful things". It was demonstrated that Ibn Ya'ī̌s and al-'Astarābād̄ī adopted al-Jaḥiz’s fivefold categorization, although the distinction between oral speech and writing (and the resulting exclusion of written words from the definition of 'word') seems unjustified in the context of their respective discussions.

As for the fivefold classification of definite nouns, it was accepted by most grammarians starting with Sïbawayhi, despite the fact that in such a scheme it is difficult to find the right place for relative pronouns (that may appear as nouns prefixed by a definite article, but differ from them in some features). This difficulty led Ibn 'Aqīl and Ibn Hišām to place

\footnotetext{
169 Al-'Astarābādīi, Šarḥ II: 384.

170 See SARTORI, forthcoming: Conclusion, where a parallel is drawn between apposition in Arabic grammar and "non-restrictive modifiers" in French grammar.

171 See, e.g., al-'Astarābād̄ī, Šarh I: 362, 386; II: 233.

172 See, e.g., ibid. I: 360, 364, 438; II: 378; III: 133.

173 See, e.g., SHEYнAтоviтch 2018: 31-41 for some examples demonstrating al-'Astarābād̄ī’s originality and non-conformism.

174 See ḤASAN 1964 III: 355-545.
}

jais 19 (2019): 81-111 
relative pronouns in a separate category (thus obtaining a sixfold categorization of definite nouns).

The fivefold classification of tanwīn seems to have begun with al-Zamahšarī. Ibn Ya $\mathrm{a}^{\mathrm{i}} \overline{\mathrm{S}}_{\mathrm{S}}$ criticizes him for not including another type of tanwīn (namely tanwīn al-muqābala) in this model, but succeeds in retaining a list of five types by combining two types mentioned by alZamahšarī in a single category. Al-'Astarābādī demonstrates that tanwīn al-muqābala is actually tanwin al-tamakkun (and thus blurs the border between two categories out of the five); he also finds a common denominator for the five types of tanwin and the nün of the ending of the dual and sound masculine plural. This notwithstanding, he keeps speaking about the five types of tanwīn. Interestingly enough, al-Zamahšarī, al-'Astarābādī and others view tanwīn as an exclusive attribute of nouns, but still include in their classifications rhyme-related tanwins that can also join verbs. Al-Širbīin is particularly aware of this problem.

Ibn 'Ușfür seems to model his presentation of the definite article after his presentation of tanwin types (i.e., five types of which four are unique to nouns). Retaining the fivefold categorization (and/or retaining the symmetry between two discussions) is so important to him that he makes efforts to present the apparent six types of definite article as five types. This categorization is by no means necessary, as is easily proved by Ibn Hišām's model, which is totally different from Ibn 'Ușfür's, including three main types with intricate subdivisions.

The last division examined in this article is that of tawābic. Most medieval grammarians speak of five tawābic; however, al-Zajjājī seems to start a tendency of speaking about four only. This confusion is apparently caused by 'atf al-bayān. Those who divide the tawābic into four either do not distinguish between 'atf al-bayān and apposition, or subsume the former under the title 'atf (together with 'atf al-nasq 'coordination'). Al-'Astarābādī says explicitly that he considers the distinction between 'atf al-bayān and full substitution unjustified; he refutes the other grammarians' arguments in favor of such a distinction. However, he keeps using the term "five $t a w a \bar{a} b i$ ".

All this material demonstrates that in many cases the grammarians took pains to make the linguistic material fit into a fivefold division, while ignoring (or pretending to ignore) existing discrepancies. ${ }^{175}$ This can be explained by the grammarians' respect for their predecessors, which may have made them adhere to previously used terms and models even when they were aware of their flaws. ${ }^{176}$ Another possible explanation is the importance of

175 Additional cases, similar to those discussed in the article are the cases of "inna and "its sisters" and of "the five/six nouns". Sībawayhi (Kitāb I: 241) calls the former category al-hurūf al-hamsa "the five particles', and lists in this context 'inna, lākinna, layta, la'alla and ka-'anna. Al-Mubarrad (MuqtadabIV: 107) and Ibn al-Sarrāj ('Ușūl I: 217) speak about "the five particles", but attempt to integrate both 'inna and 'anna into the list, by stressing their similarity. Sībawayhi did not include 'anna in the list of "the five particles", because he classified it under ism. It seems that later grammarians did not adopt Sībawayhi's view of 'anna, but nevertheless kept speaking of "the five particles" (see KASHER 2010-2011 for an analysis of the relevant material). As for "the five/six nouns", SARTORI (2010) argues that han 'a thing' was removed from this category because some grammarians found it embarrassing (because it frequently refers to female genitalia), thus leaving the category with five nouns (which fits into the scheme of fivefold categorizations).

176 This is the main explanation offered by OKAZAKI (2003) for the fivefold divisions of maf $\bar{u} l$ and $m a f^{c} \bar{u} l$-like constituents accepted by many grammarians. However, he notes that this hypothesis is in- 


\section{Beata Sheyhatovitch}

the number 'five'. The fact that even al-'Astarābādīi, known for his non-conformism and originality, adheres to fivefold categorizations of tanwīns and tawābic, despite his own criticism of them, proves that the grammarians' engagement with number 'five' goes beyond mere respect for their predecessors' authority.

\section{Bibliography}

\section{Primary sources}

'Abū Hayyān, Baḥr = Muhammad ibn Yūsuf ibn 'Alī 'Abū Hayyān: Tafsīr al-Bahr al-muhịt, eds. 'Ā. 'AHMAD and 'A. MU'AWWAD. Beirut 1993.

al-'Astarābād̄ī, Šarh = Muhammad ibn al-Ḥasan Raḍī l-Dīn al-'Astarābād̄ì: Šarh al-Raḍ̄ 'alā l-Kāfiya, ed. Y. H. 'UMAR. Benghazi 1996.

al-Bag̉dādī, Hizāna = 'Abd al-Qādir ibn 'Umar al-Bag̉dādī: Huizānat al-'adab wa-lubb lubāb lisān al'arab, ed. 'A-S. M. HĀRŪN. Cairo 1989.

al-Bațalyawsī, Hulal = 'Abdallāh ibn Muḥammad al-Bațalyawsī: Kitāb al-Hulal fì 'ịslāh al-ḥalal min Kitāb al-Jumal, ed. S. 'A-K. SU'ŪDī. Iraq 1980.

Ibn al-'Anbārī, 'Asrār = 'Abū l-Barakāt 'Abd al-Raḥmān ibn al-'Anbārī: Kitāb 'Asrār al-'arabiyya, ed. M. B. AL-BAYṬĀR. Damascus 1957.

Ibn 'Aqīl, Šarḥ = 'Abdallāh ibn 'Abd al-Rahmmān ibn 'Aqīi: Šarh Ibn 'Aqūl 'alä 'Alfiyyat Ibn Mālik, ed. M. M.-D. 'ABD AL-HAMĪD. Cairo 1980.

Ibn Hišām, Muginñ = 'Abū Muhammad 'Abdallāh Jamāl al-Dīn ibn Yūsuf ibn 'Ahmmad ibn Hišām Muginī l-labīb 'an kutub al-'a'ārīb, ed. M. M.-D. 'ABD AL-HAMīD. Beirut 1991.

Ibn Jinnī, Luma' = 'Abū l-Fatḥ 'Uțmān ibn Jinnī: al-Luma' fì l-'arabiyya, ed. Ḥ. AL-MU’MIN. Beirut 1985.

Ibn al-Sarrāj, 'Ușūl = 'Abū Bakr Muḥammad ibn al-Sarī ibn Sahl ibn al-Sarrāj: al-'Ușūl fì l-naḥw, ed. M. 'UțMĀN. Cairo 2009.

Ibn 'Ușfūr, Šarh = 'Abū l-Hasan 'Alī ibn Mu’min ibn 'Alī ibn 'Uṣfūr: Šarh Jumal al-Zajjājī, ed. F. AL$\breve{S} \breve{A}^{“ A} \bar{A}$, Beirut 1998.

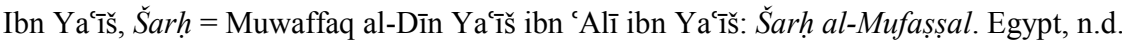

al-Jāhiz, Bayān = 'Abū 'Uțān 'Amr ibn Bahr ibn Maḥūb al-Jāhiz: al-Bayān wa-l-tabyīn, ed. 'A-S. M. HĀRŪN. Cairo 1998.

al-Jașșāṣ, Fuṣūl = 'Ahmad ibn 'Alī 'Abū Bakr al-Rāzī al-Jașṣāṣ: al-Fuṣūl fì l-'uṣūl, ed. 'A. J. ALNAŠMī. Kuwait 1994.

al-Jurjān̄̄, Muqtașid = 'Abd al-Qāhir ibn 'Abd al-Raḥmān al-Jurjānī: Kitāb al-Muqtașid fì šarh al'Ị̇āḥ, ed. K. BAHR AL-MARJĀN. Baghdad 1982.

al-Mubarrad, Muqtaḍab = 'Abū l-'Abbās Muḥammad ibn Yazīd al-Mubarrad: Kitāb al-Muqtạ̣ab, ed. M. 'A.-H. 'UDAYMA. Beirut n.d.

consistent with the term maf $f^{2} \bar{l} l \operatorname{minh} u$ (used by Sībawayhi in reference to the constituent in nașb in the tahd $\underline{d} \bar{r}$ structure) not being included by later grammarians in the $m a f^{f} \bar{u} l$ category. This fact also cannot be explained by the infrequent use of the tahd $\underline{d} \bar{r}$ structure, because another infrequent maf' $\bar{u} l m a^{\prime} a h u$ is included in the category. See OKAZAKI 2003: 28-29 for a discussion.

jais • 19 (2019): 81-111 
al-Šāfíī, Risāla = 'Abū 'Abdallāh Muḥammad ibn 'Idrīs al-Šăficī: al-Risāla. Egypt 1310 AH.

Sībawayhi, Kitāb = 'Amr ibn 'Uțmān Sībawayhi: Le Livre de Sībawaihi, ed. H. DerenBourg. Hildesheim 1970.

al-Ṭabrisī, Majma' al-bayān = 'Abū 'Alī l-Faḍl ibn al-Ḥasan al-Ṭabrisrī: Majma' al-bayān fì tafsīr alQur'ān, ed. 'I. ŠAMS AL-DīN. Beirut 1997.

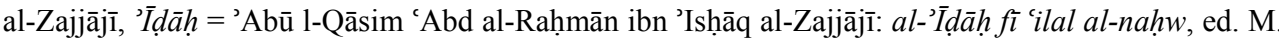
AL-MUBĀRAK. Cairo 1959.

al-Zajjājīi, Jumal = 'Abū l-Qāsim 'Abd al-Raḥmān ibn ’Isḥāq al-Zajjājīị: al-Jumal, ed. M. IBN ŠAnAB. Paris 1957.

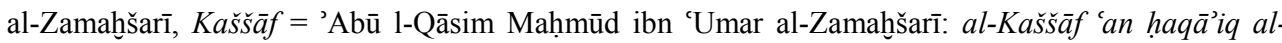
tanzīl wa-'uyūn al-'aqāwīl fì wujūh al-ta’wīl, ed. 'A.-R. AL-MAHDī. Beirut 2008.

\section{Secondary Sources}

ÅKESSON, Joyce. 2009. “Ṣarf.” In: EALL IV: 118-122.

Ayoub, Georgine. 1991. "La nominalité du nom ou La question du tanwīn.” Arabica 38: 151-213.

—. 2009. "Tanwin." In: EALL IV: 442-446.

— . 2018. "Case and Reference: The Theory of mà yanșarif wa-mā lā yanșarif in Sībawayhi's Kitāb." In: Ayoub \& Versteegh (eds.) 2018: 11-50.

— , and Kees Versteegh (eds.) 2018. The Foundations of Arabic Linguistics III: The Development of a Tradition: Continuity and Change. Leiden \& Boston: Brill.

BERnAND, Marie. 1995. "Bayān selon les Ușūliyyūn.” Arabica 42: 145-160.

BinaGHI, F., and M. SARTORI (eds.). [forthcoming]. The Foundations of Arabic Linguistics V. Leiden \& Boston: Brill.

BONEBAKKER, Seeger A. 1978. “Käfiya.” In: $E I^{2}$ IV: 411-414.

BrAY, Julia. (ed.). 2006. Writing and Representation in Medieval Islam: Muslim Horizons. London \& New York: Routledge.

CARTER, Michael G. 1981. Arabic Linguistics: An Introductory Classical Text with Translation and Notes. Amsterdam: John Benjamins B.V.

—. 2009. "Sabab." In: EALL IV: 101-102.

CONRAD, Lawrence I. 1988. "Seven and the $\operatorname{tasb}^{c}$ : On the Implications of Numerical Symbolism for the Study of Medieval Islamic History." Journal of the Economic and Social History of the Orient 31: 42-73.

DANECKI, Janusz. 2009. “Tamakkun.” In: EALL IV: 431-433.

DIEM, Werner. 1998. Fa-waylun li-l-qāsiyati qulūbuhum: Studien zum arabischen adjektivischen Satz. Wiesbaden: Harrassowitz.

EALL = Encyclopedia of Arabic Language and Linguistics, edited by K. VersteEGH, M. EID, A. ElgiBALI, M. WOIDICH and A. ZABORSKI. Leiden: Brill, 2005-2008.

$E I^{2}=$ Encyclopaedia of Islam, Second Edition, edited by P. BEARMAn, Th. BIANQuis, C.E. BosWORTH, E. VAN DONZEL, W.P. HEINRICHS. Leiden: Brill.

ESSEESY, Mohssen. 2006. “Apposition.” In: EALL I: 123-126.

FAHD, Toufic. 1993. “Nasr.” In: $E I^{2}$ VII: 1012. 


\section{Beata Sheyhatovitch}

GABUČAN, Gračija M. 1972. Teorija artiklja i problemy arabskogo sintaksisa. [Theory of the article and problems of Arabic syntax]. Moscow: Nauka. [In Russian].

GäTJE, Helmut. 1970. "Zum Begriff der Determination und Indetermination im Arabischen.” Arabica 17: $225-251$.

Giolfo, Manuela, and Kees Versteegh (eds.). 2019. The Foundations of Arabic Linguistics IV: The Evolution of Theory. Leiden: Brill.

Guillaume, Jean-Patrick. 2011. "Defining the Word within Grammatical Tradition.” In: LANCIONI \& BETTINI (eds.) 2011: 49-68.

HASAN, 'Abbās. 1964. Al-Naḥw al-wāfì ma'a rabtihi bi-l-'asālīb al-rafíca wa-l-hayāt al-lugiawiyya almutajaddida. First edn. Cairo: Dār al-Ma'ārif, 1960.

HeInRICHS, Wolfhart P. 1995. “Ru’ba b. al-'Adjdjādj.” In: EI² VIII: 577-578.

KASHER, Almog. 2010-2011. "Early Transformations of Theories about anna and an and the Standardization of Arabic Grammatical Tradition." Zeitschrift für Geschichte der Arabisch-Islamischen Wissenschaften 19: 243-256.

LanCiOni, Giuliano, and Lidia BetTini (eds.). 2011. The Word in Arabic. Leiden \& Boston. Brill.

LANE, Edward W. 1863-1893. Arabic-English Lexicon. 8 vols. London: Williams and Norgate.

LARCHER, Pierre. 1991. "D'une grammaire l'autre: Catégorie d'adverbe et catégorie de maf'ūl muțlaq." Bulletin d'études orientales 43: 139-159.

— . 1992. "Quand, en arabe, on parlait de l'arabe ... (III) Grammaire, logique, rhétorique dans l'islam postclassique." Arabica 39: 358-384.

—. 2011. "What is a kalima?" In: LANCIONI \& BeTtini (eds.) 2011: 33-48.

LAROCHE, Roland A. 1995. "Popular Symbolic/Mystical Numbers in Antiquity." Latomus 54: 568576.

LEvin, Aryeh. 1995. "The Arab Grammarians' Theory of 'amal." Jerusalem Studies in Arabic and Islam 19: 214-232.

- 1997. "The Theory of al-Taqdīr and Its Terminology." Jerusalem Studies in Arabic and Islam 21: $142-166$.

Marogy, Amal E. 2010. Kitāb Sībawayhi: Syntax and Pragmatics. Leiden.

MARquet, Yves. 1971. "Ikhwān al-Ṣafā̄." In: $E I^{2}$ III: 1071-1076.

MONTGOMERY, James. E. 2006. “Al-Jāḥiẓ’s Kitāb al-Bayān wa al-Tabyīn.” In: BrAy (ed.) 2006: $92-$ 152.

NaSR, Seyyed Hossein. 1993. An Introduction to Islamic Cosmological Doctrines. Albany, NY: State University of New York Press.

OKAZAKI, Hideki. 2003. "The Subcategory of maf'ül in Arabic Grammatical Tradition: Ibn AsSarrāğ's Classification and the Later Transition." Kansai Journal of Arabic and Islamic Studies 3: 15-32. [In Japanese].

Owens, Jonathan. 1988. The Foundations of Grammar: An Introduction to Medieval Arabic Grammatical Theory. Amsterdam-Philadelphia: John Benjamins.

Ron-GilboA, Guy. 2017. The 'Ajā’ib Theme in Four Medieval Works. Ph.D. Dissertation. Hebrew University of Jerusalem. [In Hebrew].

SADAN, Arik [forthcoming]. "Less familiar types of 'an according to Arabic grammarians." In: SHEYHATOVITCH \& KASHER (eds.) (forthcoming).

ز 19 (2019): 81-111 
SaKaedani, Haruko. 2019. "What is Definiteness in Arabic? Focusing on Proper Nouns for Genera and asmä mubhama 'Ambiguous Nouns'.” In: GIOLFO \& VerSTEEGH (eds.) 2019: 233-252.

SARTORI, Manuel. 2010. "Les 'six noms': grammaire arabe et pudibonderie.” Synergies Monde arabe 7: $35-45$.

— . [forthcoming]. "Suprasegmental Criteria in Medieval Arabic Grammar." In: BINAGHI \& SARTORI (eds.) [forthcoming].

SCHACHT, Joseph. 1960. “Ahkām.” In $E I^{2}$ I: 257.

SCHIMMel, Annemarie. 1993. The Mystery of Numbers. New York \& Oxford: Oxford UP.

Sheyhatovitch, Beata. 2012. The Notion of fầida in the Medieval Arabic Grammatical Tradition. M.A. thesis. Tel Aviv University. [In Hebrew].

- 2016. Raḍ̄ l-Dīn al-Astarābād $\bar{\imath}$ and His Position in Medieval Arabic Grammatical Theory: A Study on the Distinctive Terminology and Methodology in Šarh al-Kāfiya. Ph.D. dissertation. Tel Aviv University. [In Hebrew].

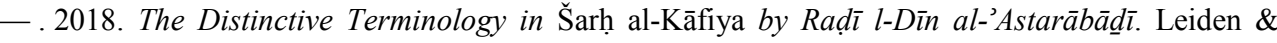
Boston: Brill.

- . 2019a. "The Concept of tawtiia in Medieval Arabic Grammatical Tradition." In: Giolfo \& VerSTEEGH (eds.) 2019: 274-294

- . 2019b. "The Distinction between the General and the Specific in Sharh al-Kāfiya by Raḍi al-Dīn al-Astarābādhī." Forthcoming in Jerusalem Studies in Arabic and Islam 46.

- . [forthcoming]. "The Theory of Definition in Šarh al-Kāfiya by Raḍī 1-Dīn al-'Astarābādīi." In: SHEYHATOVITCH \& KASHER (eds.) (fortcoming).

—, and A. KASHER (eds.). [fortcoming]. From Sïbawayhi to 'Ahmad Hasan al-Zayyāt: New Angles on the Arabic Linguistic Tradition. Leiden: Brill.

Stone, Michael E. 2011. Ancient Judaism: New Visions and Views. Grand Rapids, MI, \& Cambridge (UK): William B. Eerdmans.

TALmon, Rafael. 1981. "Appositival 'atf: An Inquiry into the History of a Syntactic Category." Arabica 28: 78-292.

The editors of $E I^{2}$. 1993. "Al-mughayyabāt al-khams.” In: $E I^{2}$ VII: 346-347.

VersteEgh, Kees. 1995. The Explanation of Linguistic Causes: az-Zağğāǧı̆’s Theory of Grammar: Introduction, Translation, Commentary. Amsterdam \& Philadelphia: John Benjamins.

—. 2009. "Sifa." In: EALL IV: 219-222.

Wright, William. 1967. A Grammar of the Arabic Language. Cambridge: Cambridge UP. (First edn London \& Edinburgh: Williams and Norgate, 1862.)

(C) Beata Sheyhatovitch, Department of Arabic and Islamic Studies, Lester and Sally Entin Faculty of Humanities, Tel Aviv University, Israel

$\triangleleft$ beatashe@mail.tau.ac.il 